Journal of University of Raparin $\quad$ كوّقارى زانكوّى رايهِرين $\quad$ E-ISSN: 2522 - 7130 P-ISSN: 2410 - 1036

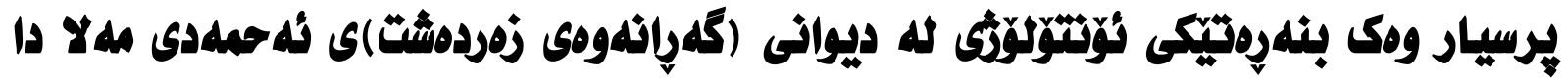

هلةًار ئه حهد علبلدولفهفوور

بهشى كوردى، فاكهلتى ئاداب، زانكوى سوّران، سوّران، هـريَّى كوردستان، عيرّاق. Hيميل: Hazhar.abdulghafur@soran.edu.iq

محdمهلد نهبى نيبيراهيم

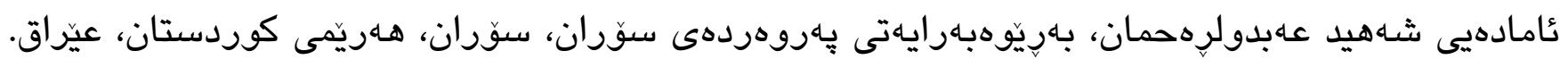
ئيمهيل: Mhamad.nabe88@gmail.com

يوخته

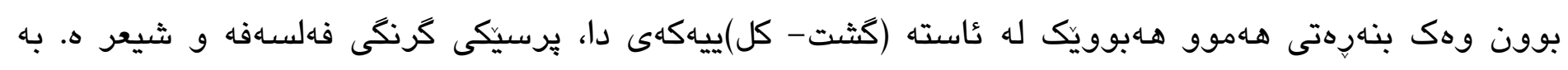

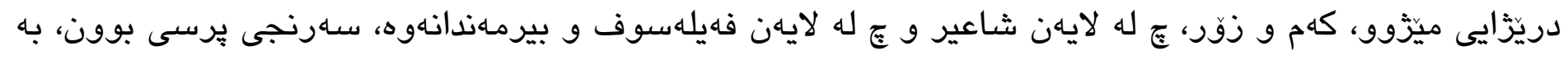

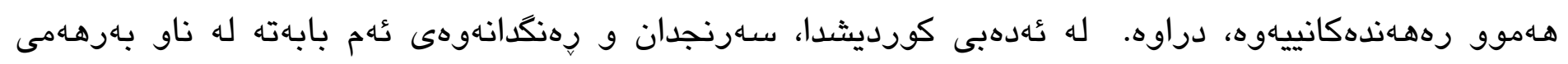

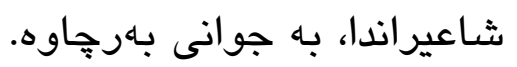

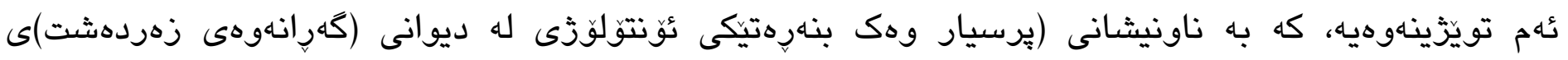

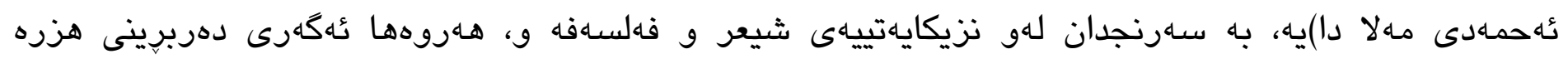

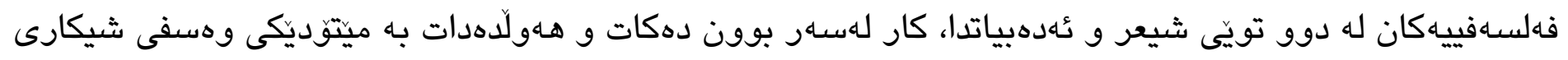

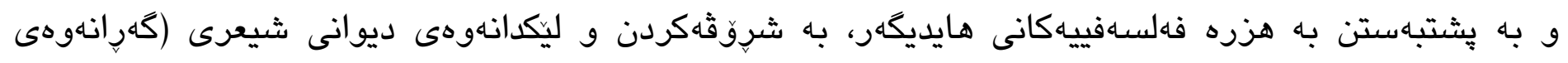

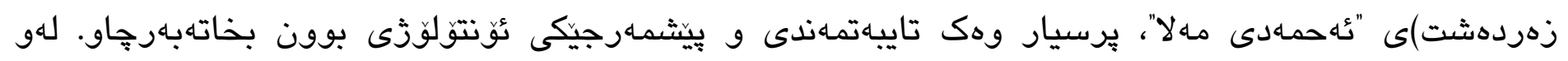

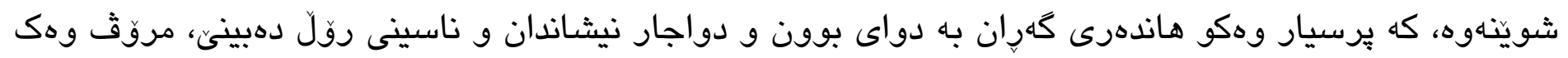

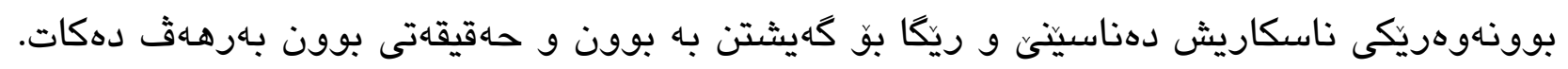

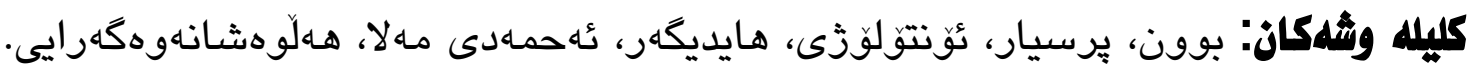




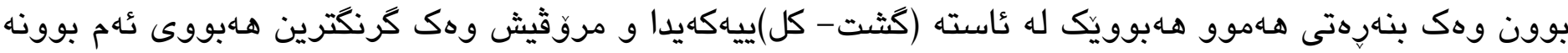

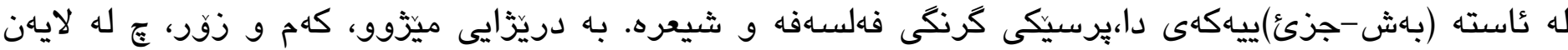

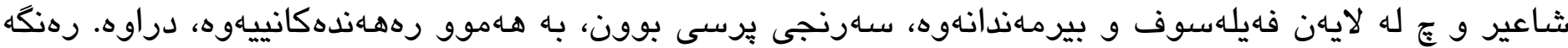

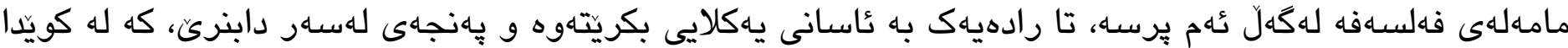
فهيلهسوف و بيرماهدان، باسيان له بوون كردووه، بهلام بيكّومان بو شيعر، به سهرنجدان له تايبهتمـهندييه

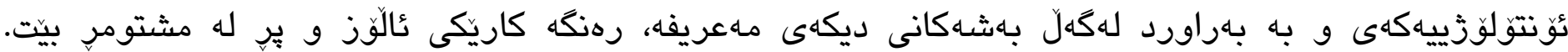

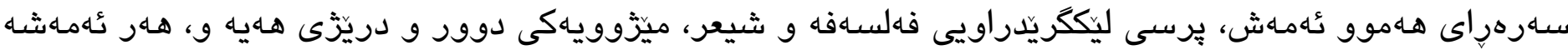

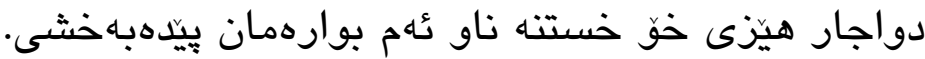

له ناو شيعردا، له دنياى هـهتهوه بكره، تا دنياى خهيال و ويناكردناهانى مروث، بابهتى شيعرن و، ناوهروك و

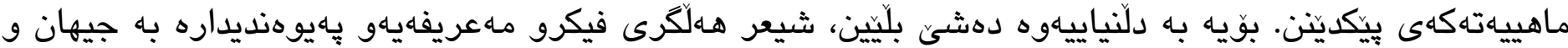
بوونى مرويى. به مانايهكى تر، به سـرنجدان له روانكَه و رهههنده جياوازهانى هزر له لايهك و، ماهيهتى ئهدبيات له لايهكى تر، دهتوانين بليّين، له شيعردا كَران به دواى حهقيقها شتيكى بنهرهتييه، يان به دهربرينيكى تر، له شيعردا بهشيكى راستييهكانى بوون دهبينرين.

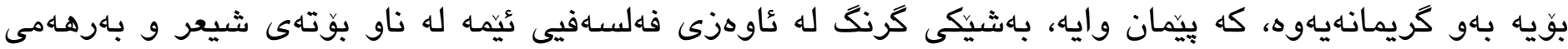

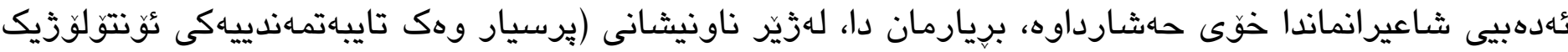

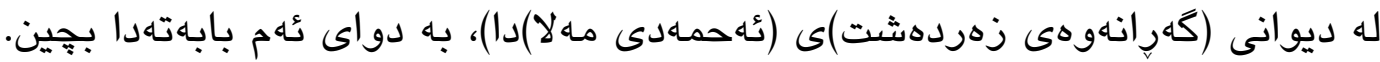

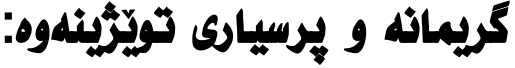

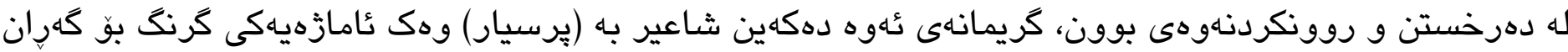
به دواى شتيك و تيشكخستنهسهى و دواجار دهرخستنى، راستييهكانى بوون دهردهخات و دواجار ليّرهبوون و

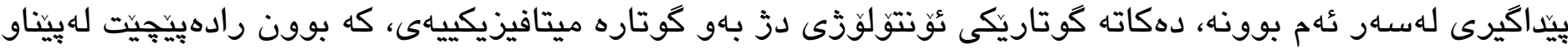
دونيايهكى ديكهى دهرهوهى بوون.

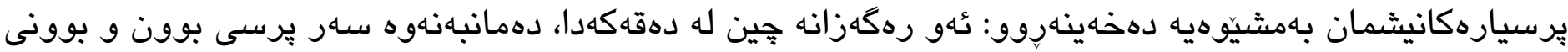

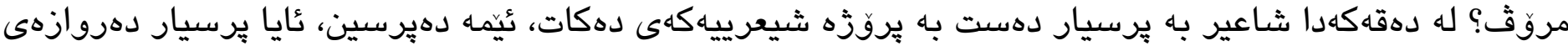


نزيكبوونهوه له "بوون"مان بوّ دهكاتهوه؟ يُرسيار ع كرنكييهكى هـيه له دهرخستنى ماناكانى بوون؟ دواجار دووباره

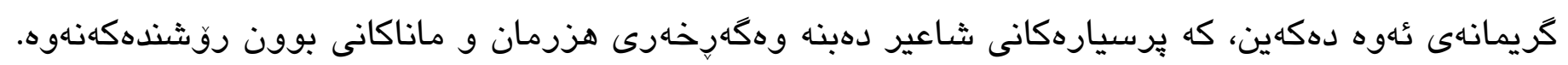

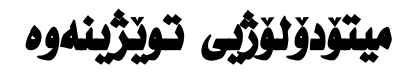

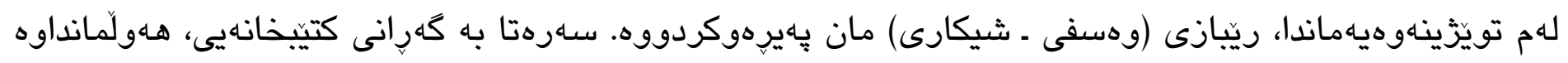

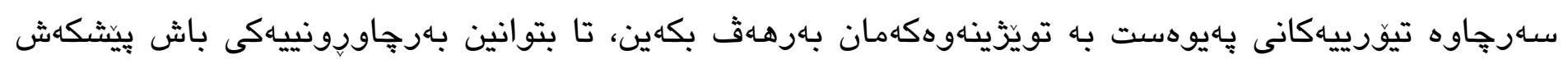

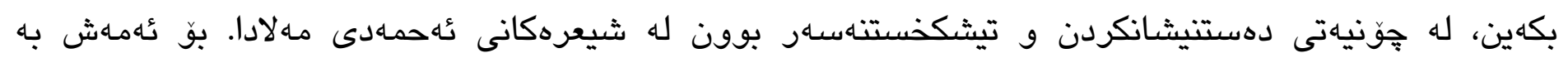

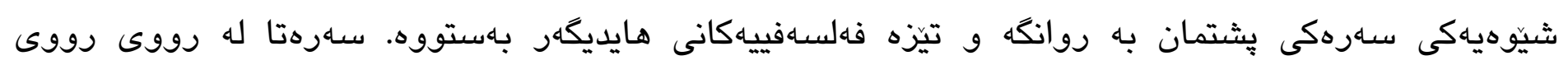

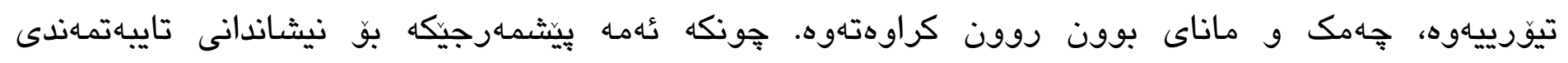

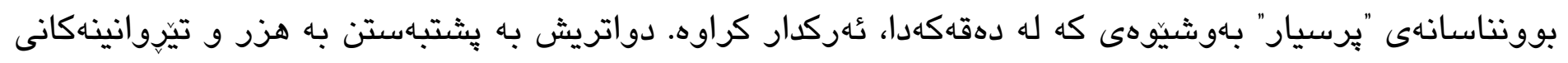

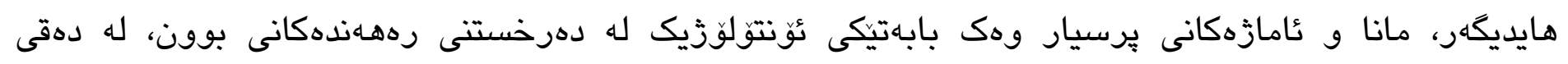

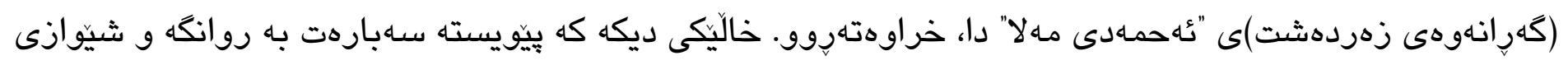

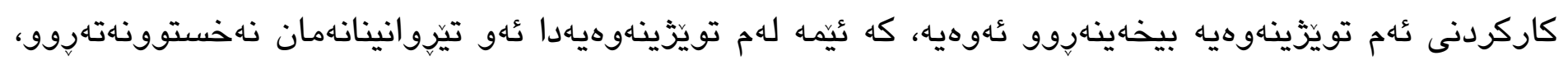

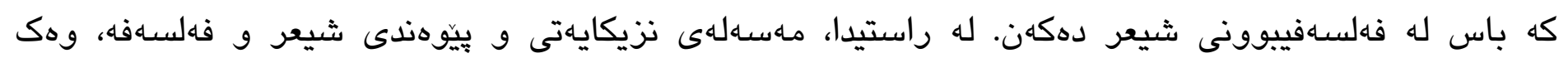

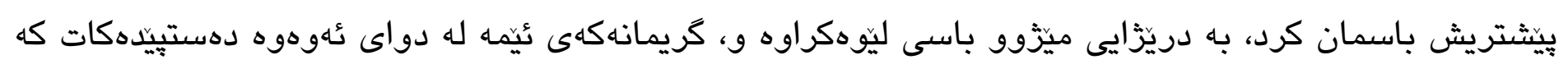

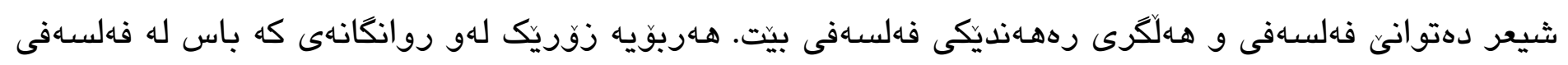

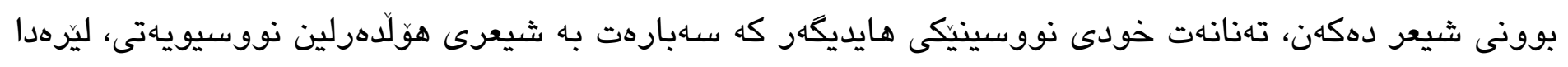

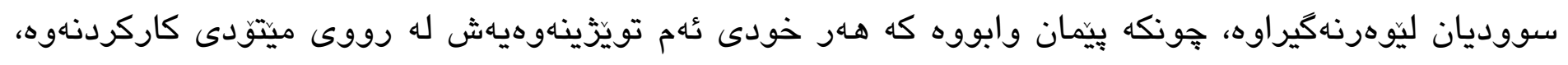
شتيكى هاوشيّودى ئهوانه.

\section{واتاكاذى بووز، بووز لاى هايليكهر}

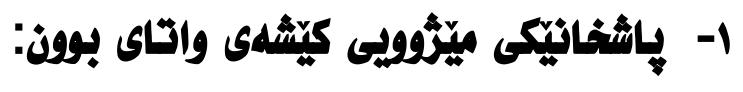

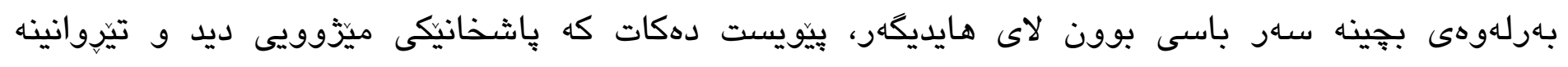

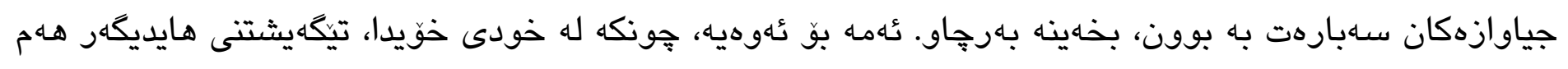

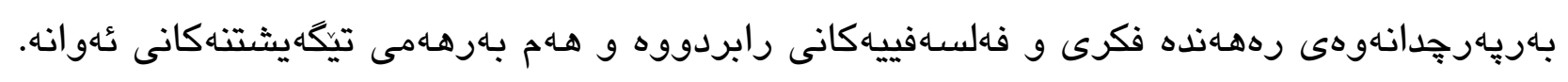

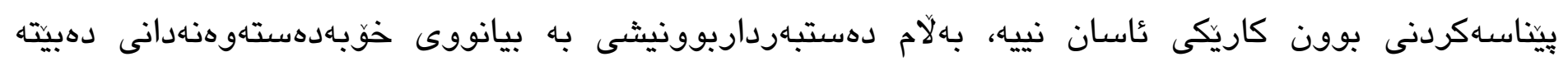

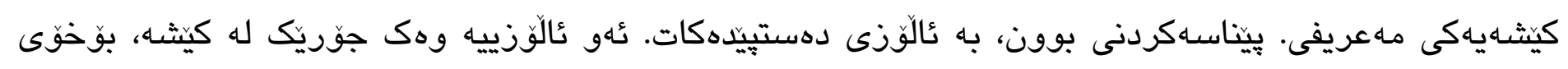


دهبيته هـاوليَكيش بو شـانوكهوكردنى بوون و نزيكبوونهوه له ماناكانى، جونكه بهكيشاكردن(problematization)

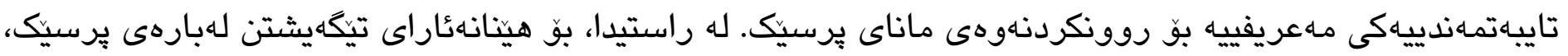

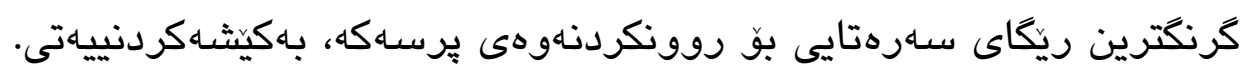

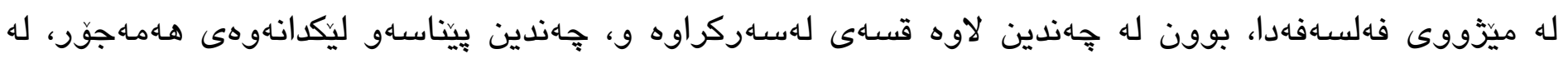

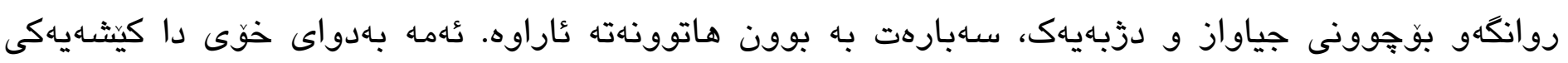

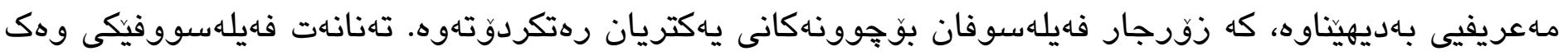

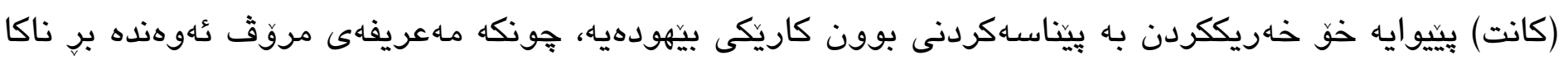

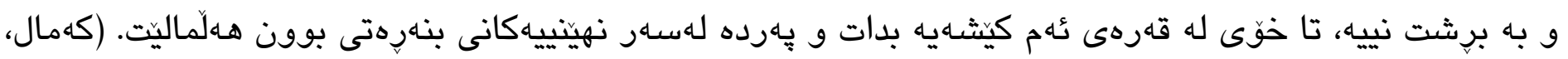

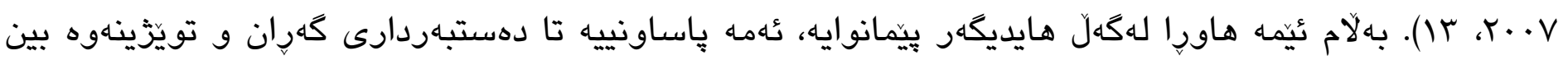

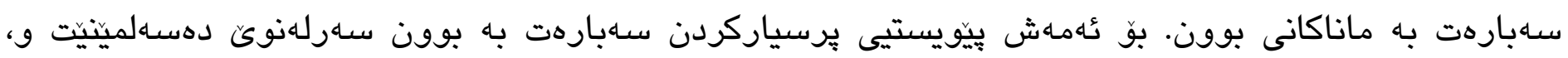

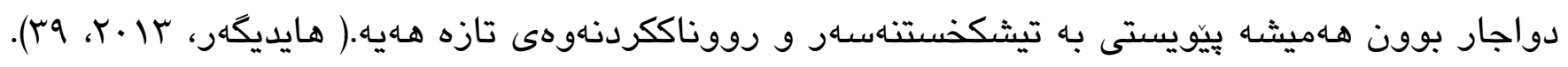

هـبوونى ليكدانهوهى فهلسهافيى جياواز سابارهت به بوون، وايكردووه جِهندين رهوت و ريّيازى فهلسهافيى جياجيا

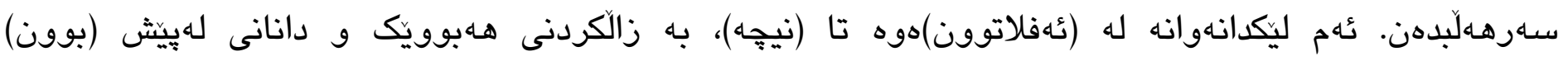

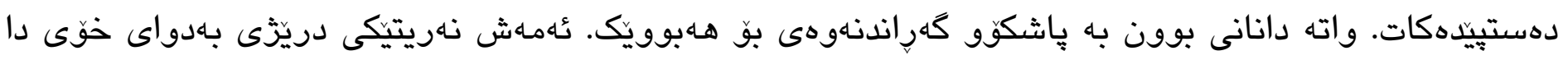

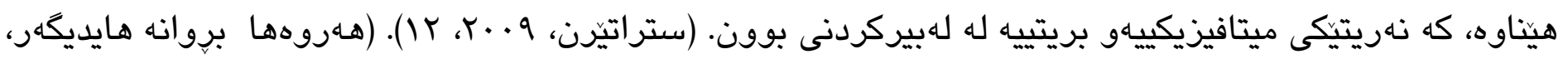
(rV r r r r r

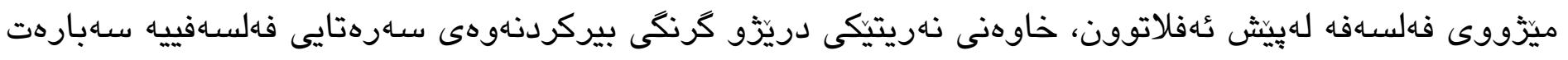

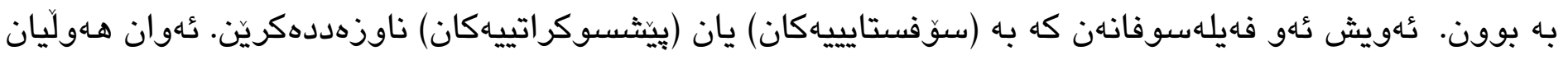

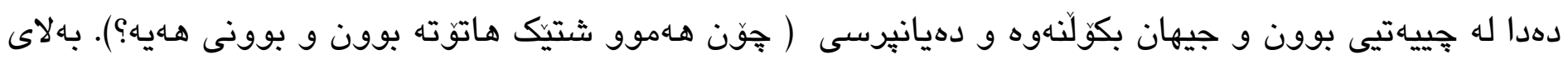

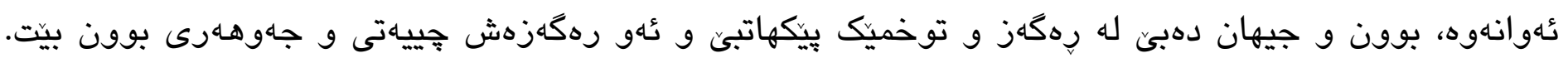

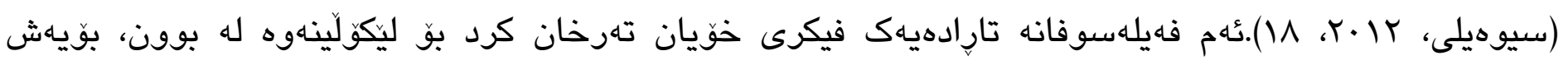

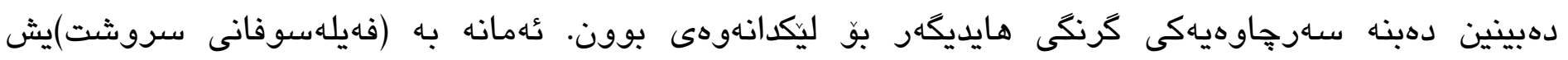

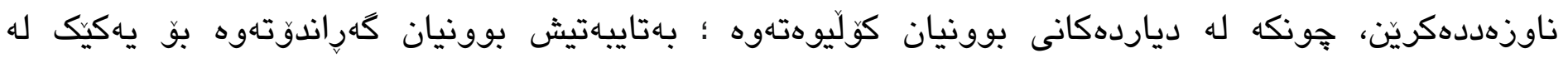

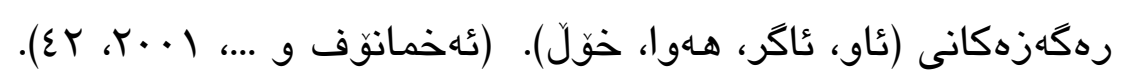

ئهلاتوون(عV

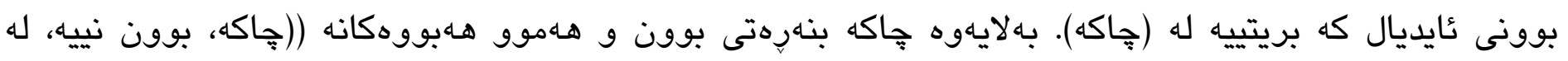




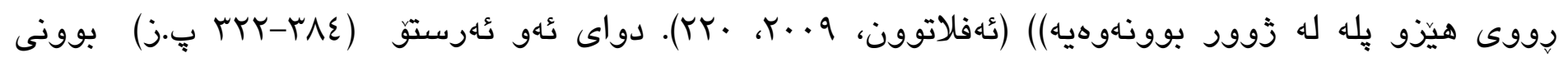

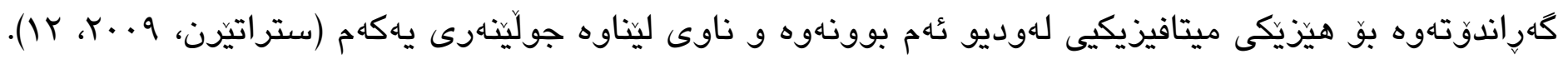

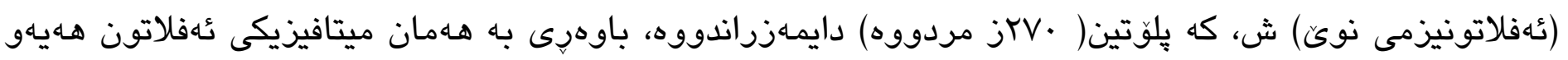

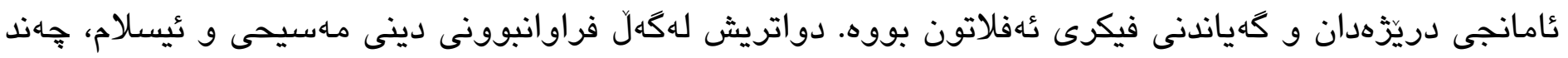

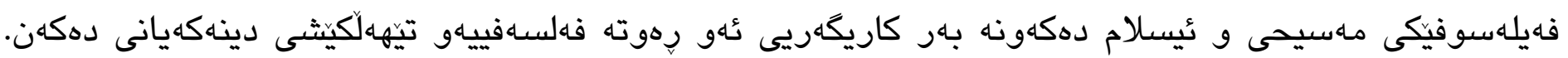

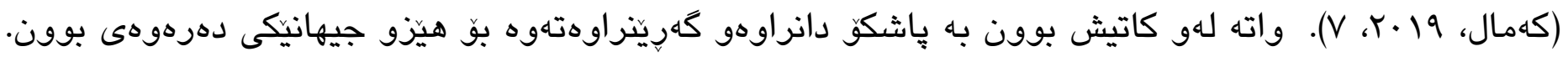
دواتر، فهيلهسوفى فهرهنسى ديكارت (1097- 170) كوجيتوكهى خُّى دامهزراند و كوتى (من بيردهكهمهوه كهواته

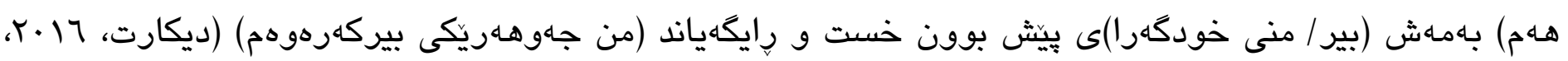

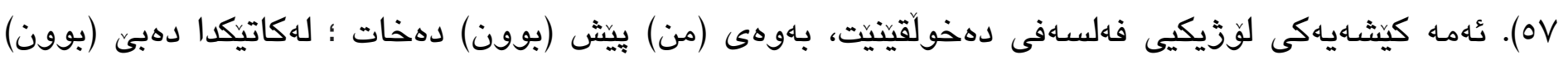

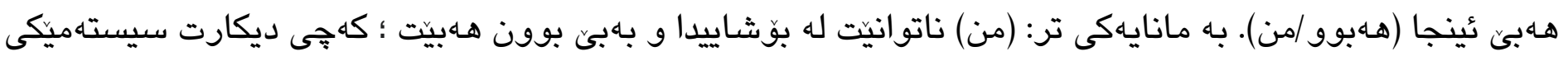
ميتافيزيكيى دادهنيت و بوون دهكاته ياشكوى بير.

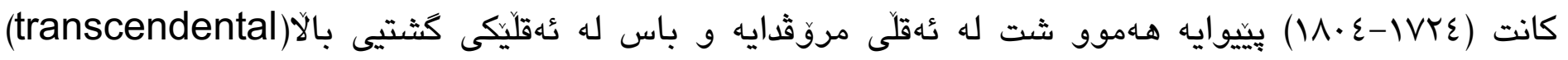
دهكات و، رِوّلى ميّزوويى مروّق له داهينانى ناوهروكى زَيان كهمدكاتهوهو، ئهقِّانييهت (rationalism) دهكاته

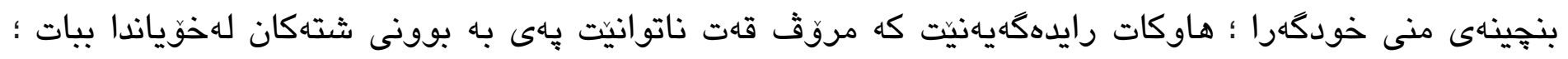

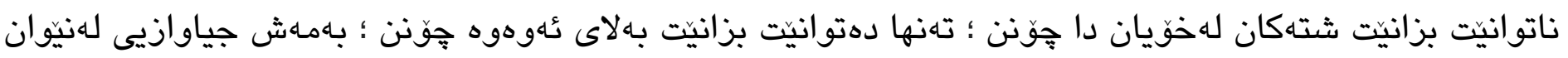

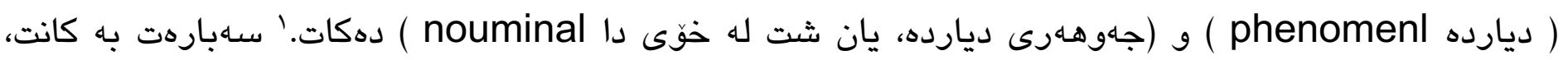
هايديكهر دهنوسيّت ((دوو شت بوون به رِيَّر له عاست تيكَهيشتى كانت دا، يهكهم بايهخنهان به كرفتى "بوون" و

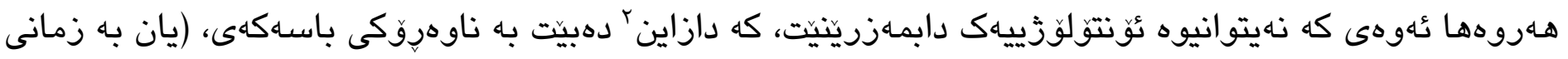

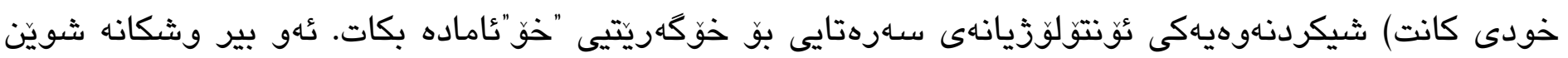
ديكارت كهوت)( (هايديكهر، سار •r، 77).

فهيلهسوفانى ياش ديكارت و كانت ((له سيّينوزا و لايبنيزهوه بو هيكل، له ماركسهوه بوّ نيتشه، لهنيّو نهريته

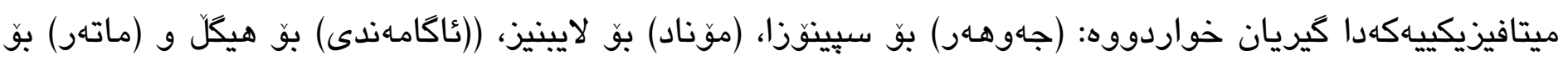

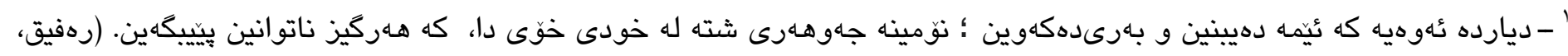

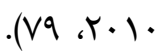

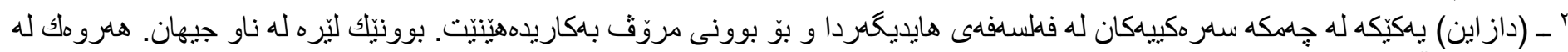

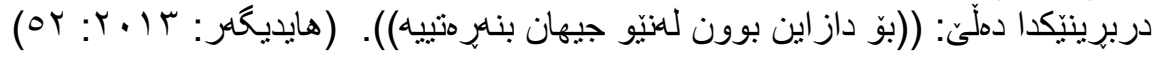
203

DOI:https://doi.org/10.26750/Vol(8).No(3).Paper11 http://journal.uor.edu.krd/index.php/JUR Vol.8. No.3,September.2021 


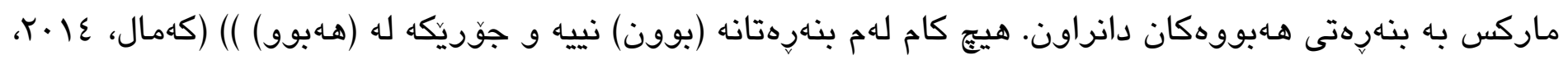

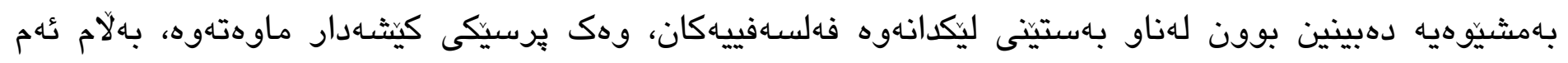

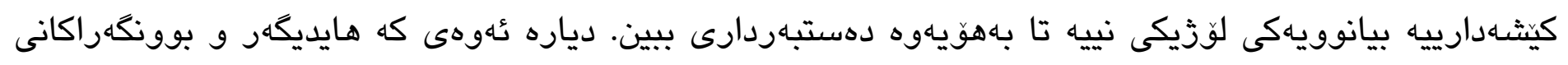

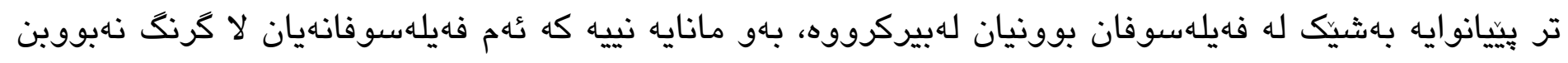

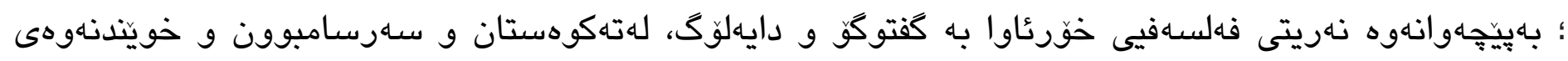

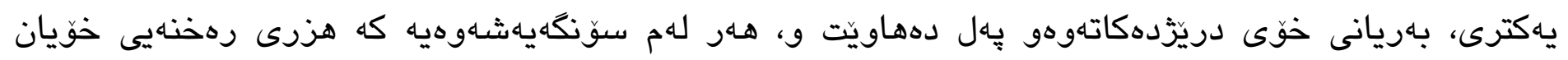
دهخهنهروو، جهونكه رهخنهارى و شروّثكارى، بوّخوى كرنكترين خزمهتيكه بـ نووسين بكريّت. ئهمانيش هـر كُهمهيان كردووه.

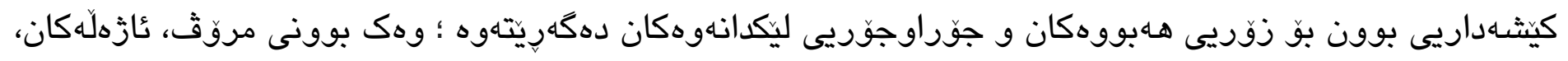

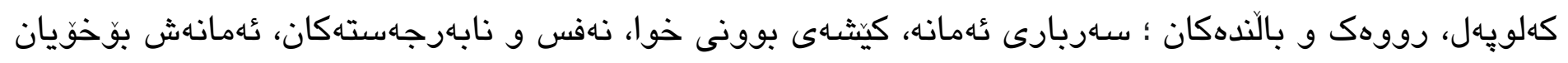

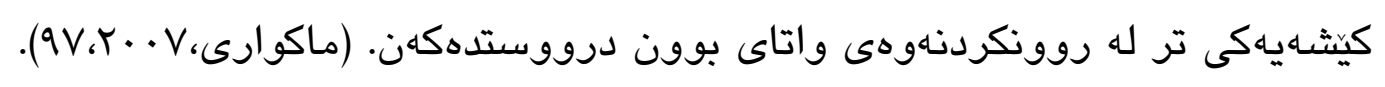

دواجار دهبينين، يِرسى بوون له ميّزووى فهلسـهذها به كيشـهداريى و لهنيّ تهمدا مانهوه سـرهتاتكى دهكات. فهيلهسوفان زياتر له هـبووهكانيان كوليوهتهوه، بهلاّم رووونكردنهوهى واتاى بوون، بهو شيّوهيهى ثامانجى

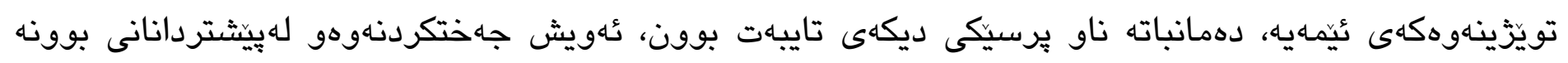

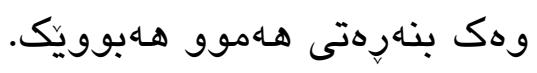

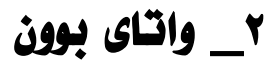

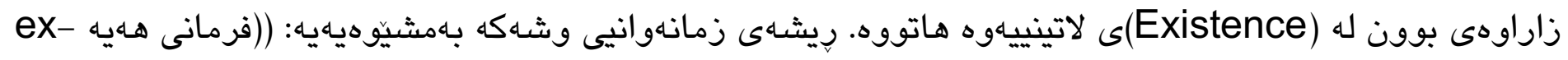

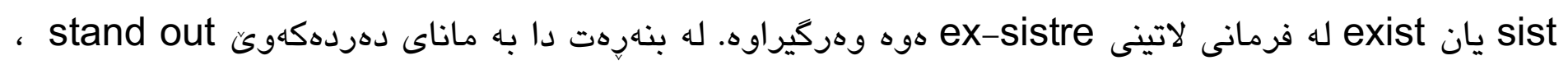

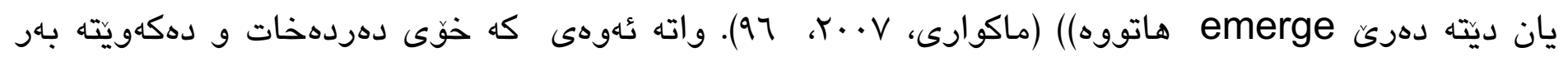
روّشنايى تيكَهيشتن. هـاموو تُهوهى له بوون دا دهردهكويت و خوّى دهردهخات، بريتييه له بوون و بوونى شتهكان

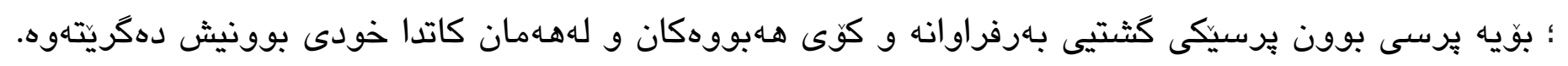

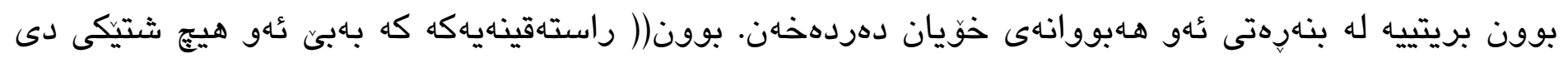
ناييت و ئيمهاش بهشيكين لهو ؛ ثٔهوهى دهيزانين لهبارهى ئهوهوهيهو هـر شتيكيش له بوون بهدهر بيت ثٔهوا نييهو

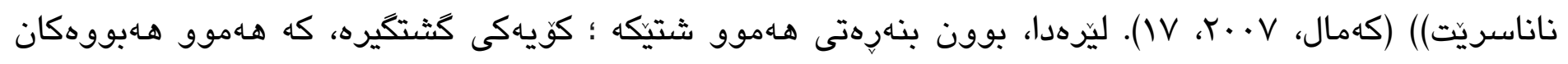




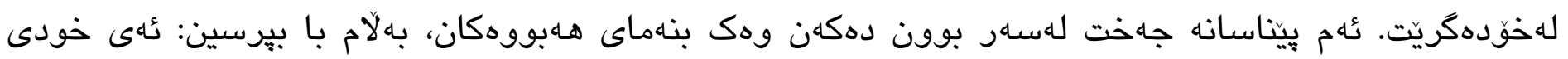

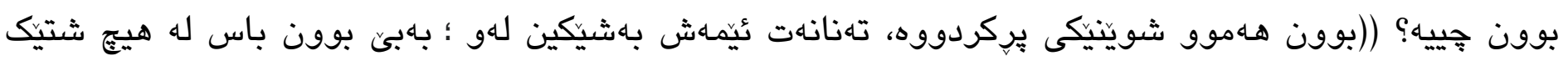

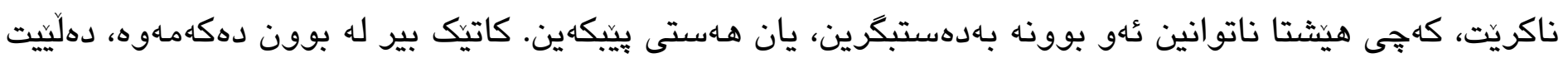

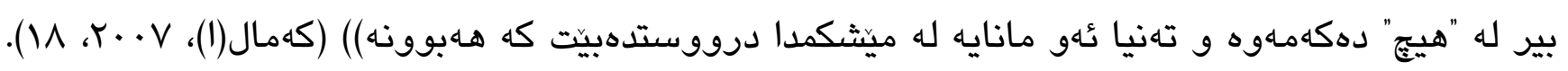
له كوّى ليكدانهوهكان بوّ ماناى بوون، دهكَهينه ئهو راستييهى كه دوو جوّر راستهقينهمان دهستكير دهبن: يهكهم:

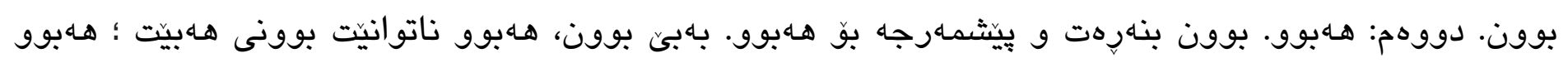

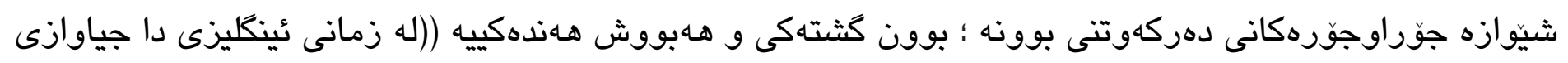

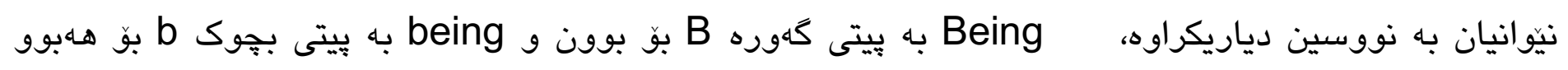

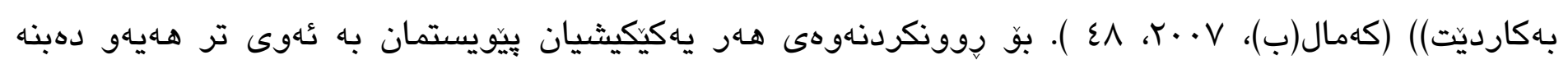
سـاهُجاوه بوّ يهكترى.

\section{بوون لاى هايليكهر}

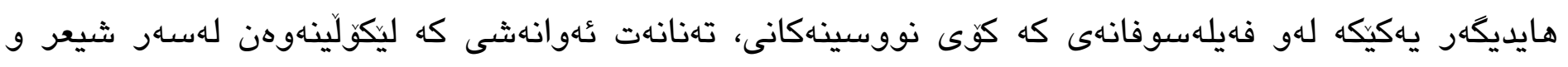

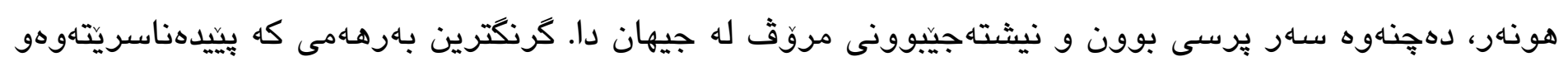

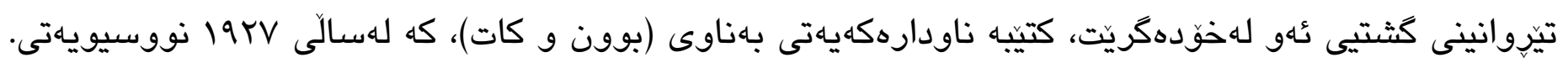

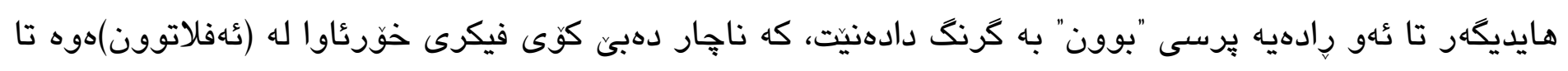

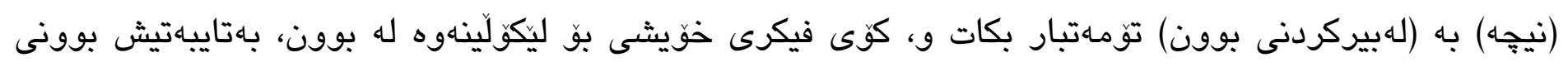

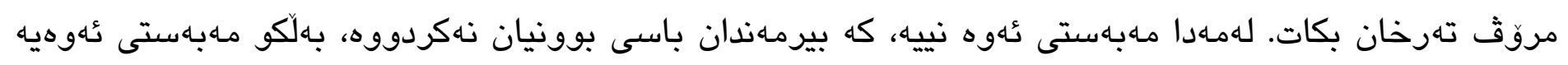

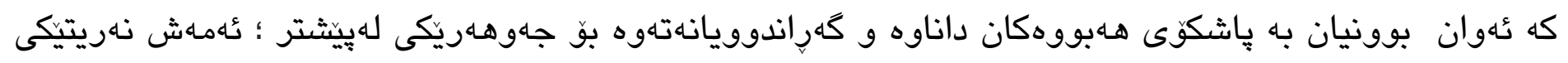

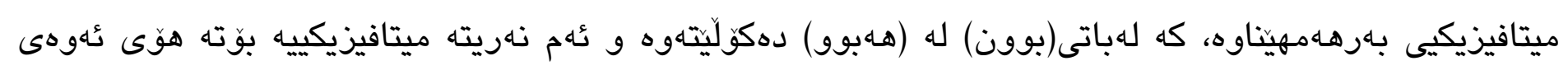

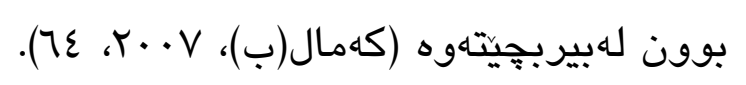

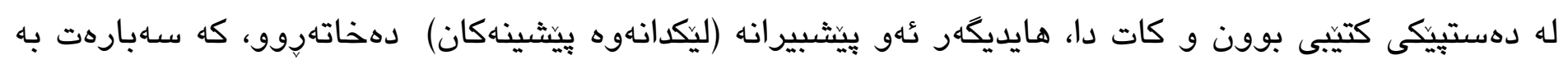

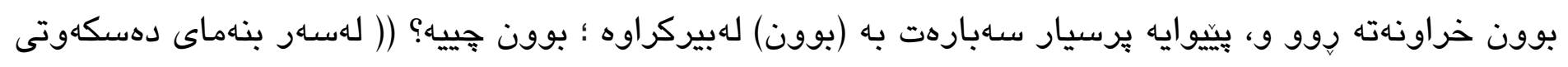

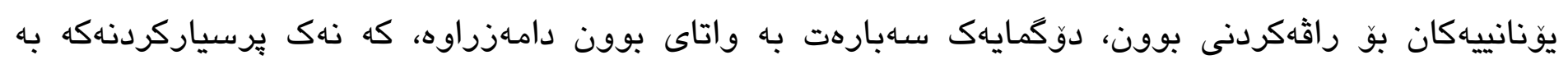

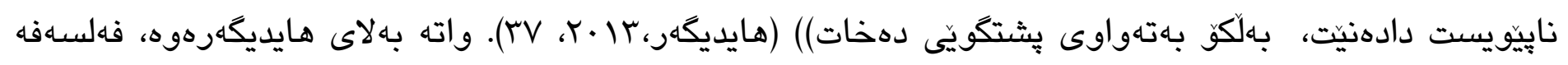

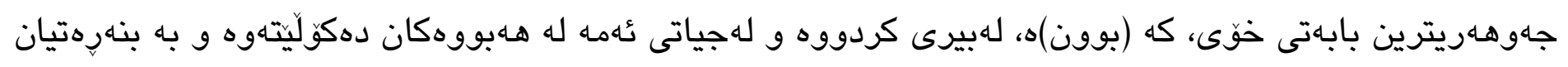

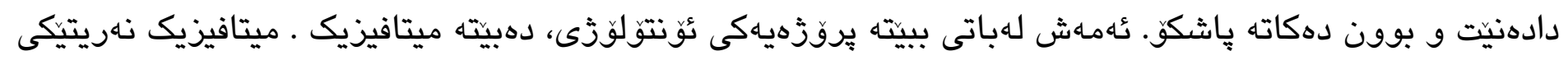


زالّبووى بيركردنهوهى فهلسهفييه، (هـبوو) له جيكّهى (بوون) به بنهارهت دادهنيّت و له بوون ناكوَلِيتهوه ((ميتافيزيك

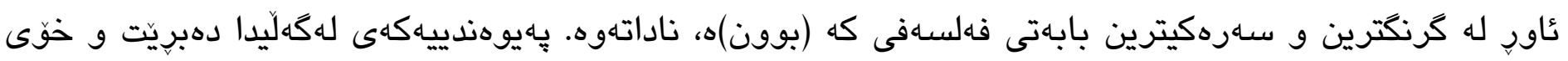

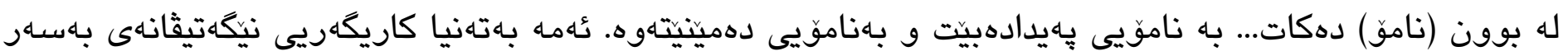

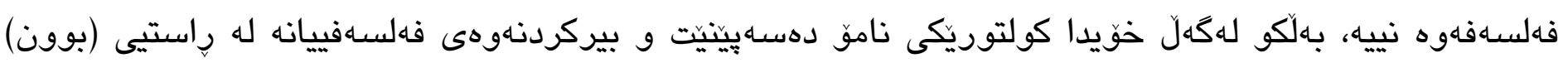

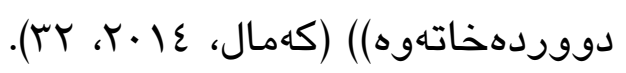

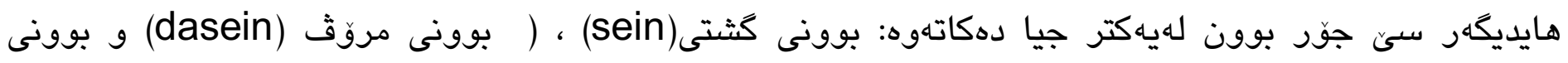

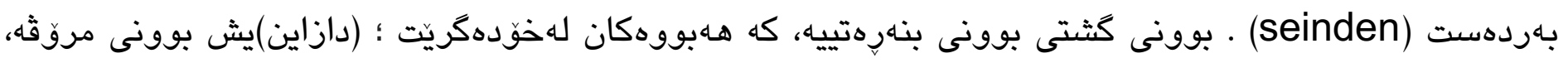

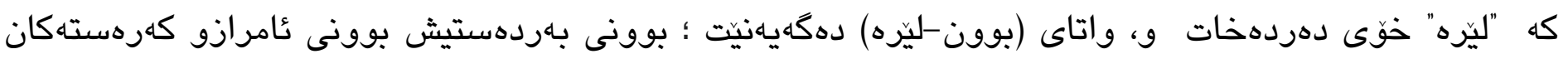

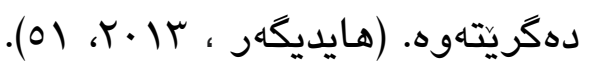

هايديكهر له فهلسهاهكهى دا، كه له (بوون و كات) دايمهزراندووه، بوون دهكاته بنهرهت و بنهما و، لهسهار ئهم

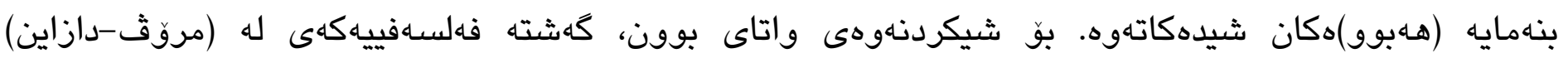

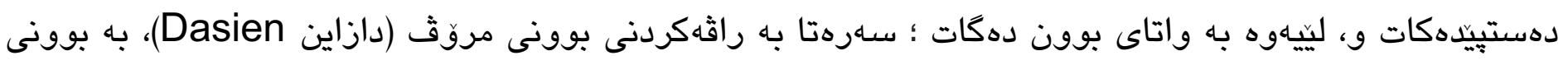

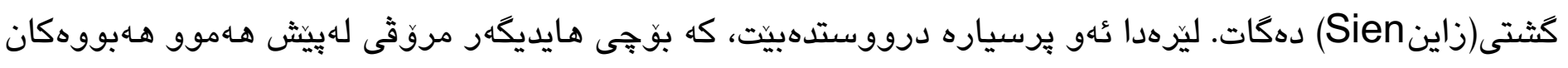

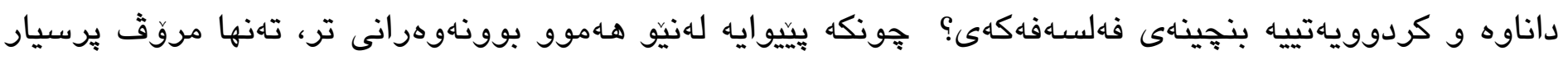

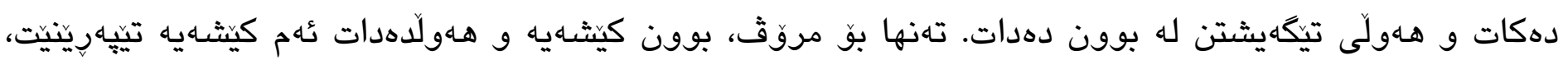

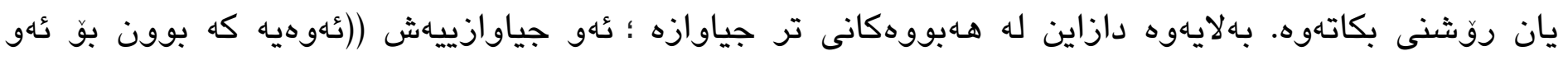

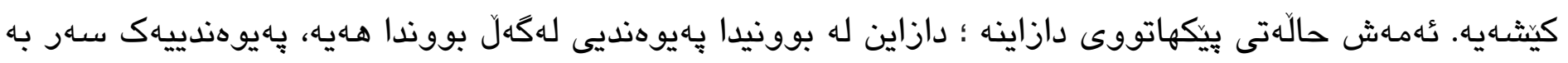
خودى بوونه) (كهمال، ع الr. • (0).

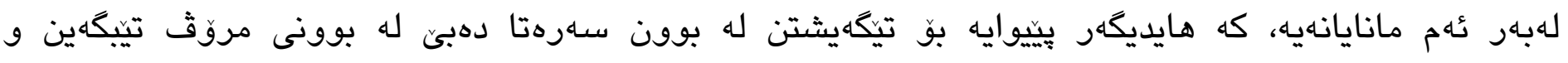

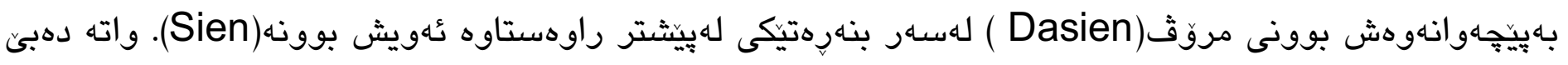

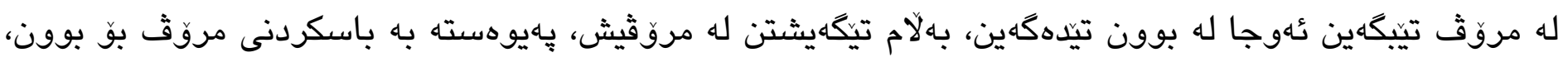
بو جيهان.

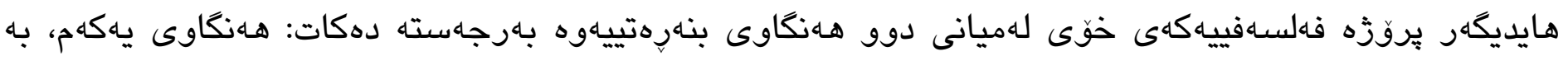

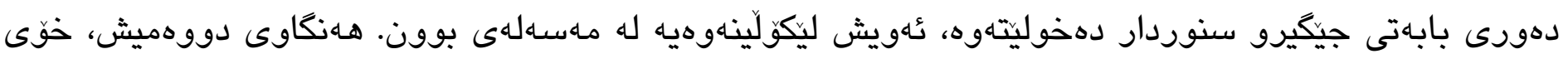

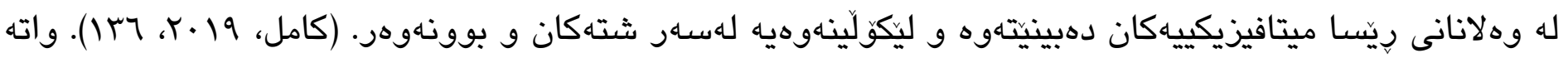

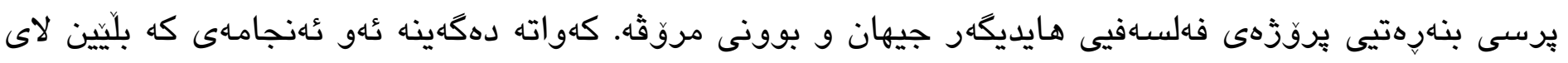




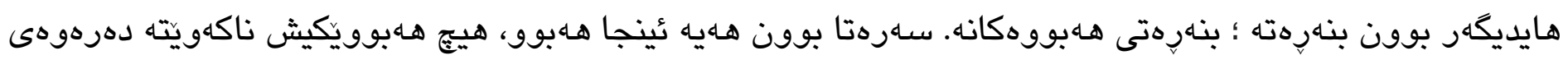
بوون، ئيّمها له بوون داين.

\section{هربسيار ومك بنهمايلهى بوّ دمرخستثى واتاى بوون}

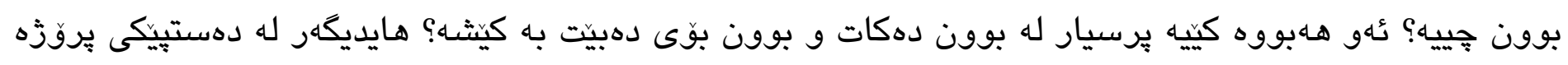

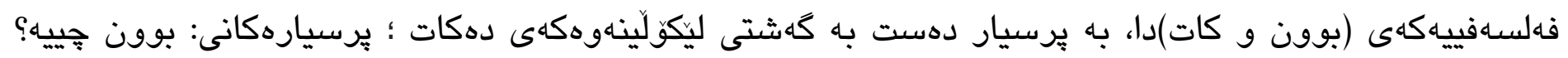

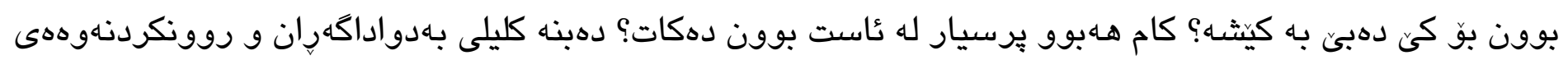

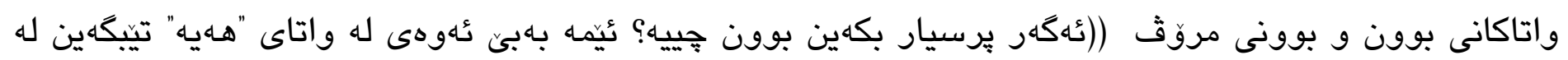

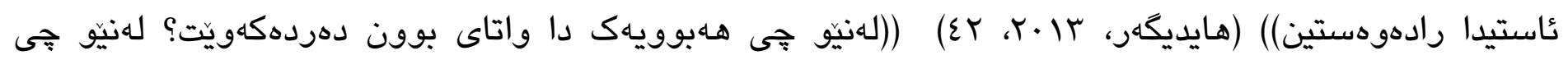

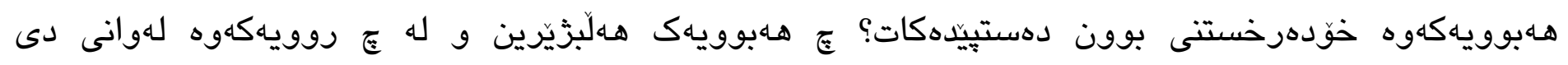

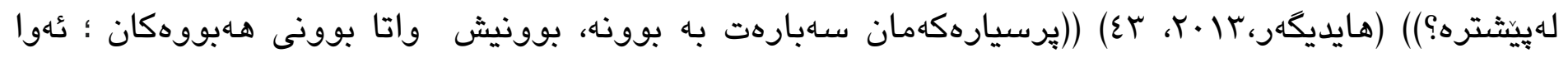

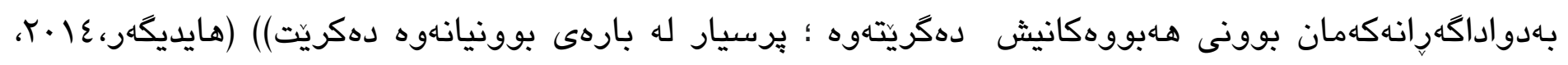

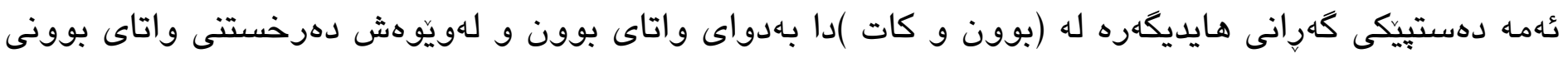

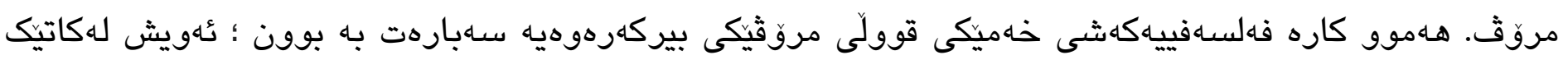
دا بوو، كه بوون لهبيركرابوو و جى ديكه جيّى بايهخى بيرمهندان نهبوو ؛ لهبِيى ثئوه شتانيكى تر ببوونه جيّى

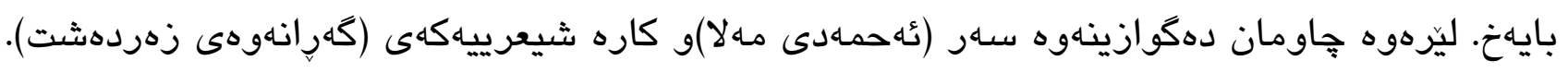

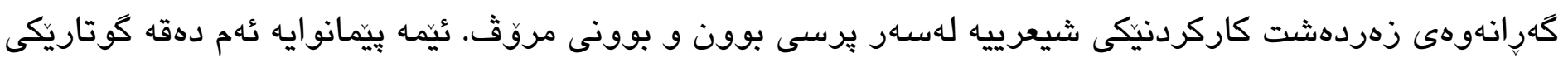

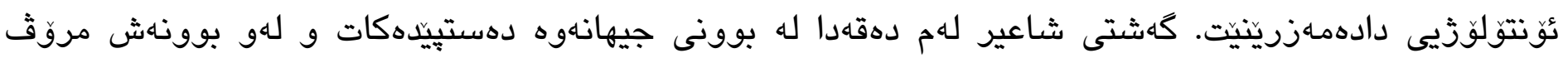
دهكاته جههقى كارهكهى. تهنانهت بوونى يـزدانيش له ميتافيزيك دادهكريّت ودهيهينيته ناو بوون، وهك ئهوهى بلّى:

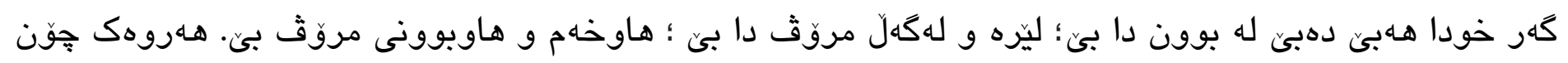

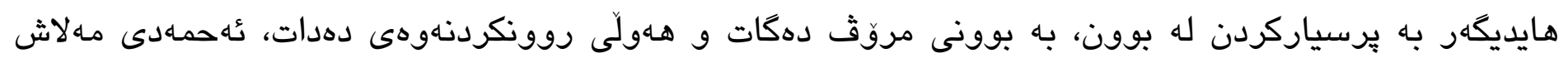

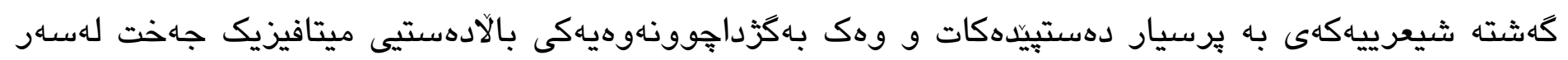
ليّرهبوون دهكات: 
بهرامبهر به خور راوهتاوم، ميّشتا نازانم ئهو بِّ من مهللهاتووه، يا من بوّ ئهو؟

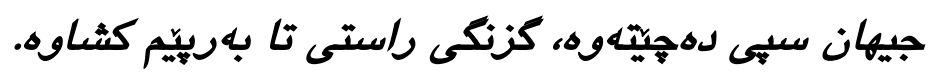

لهخوم لدهبرسم دهبى راستى جهى بجى؟ مهللهاتنى خُور راستييه، يا بوونى من ليّره؟ يا بوونى مهردووكمان؟ راستى له لدردوهى منه يان له ناوهوهمه؟ ئايا راستى لهدهرهوهيه، لهنيو تيكشكانى ئاسمانهانه، يا لهسهر تاتهبهردى تهخت نووسراودتهوه؟ ئايا رووناكييهك

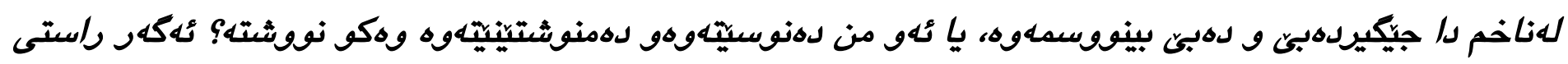

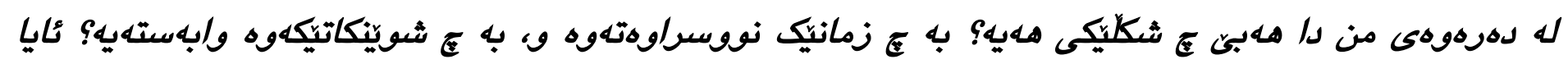
زمان له دهرهوهى بوقن هيع واتايهكى لدهبئ(مهلا، 7 ا.r.

ئهمانه دهستيّيكى يُرسياره شيعرييهكانى شاعيرن لهسهر بوون و بوونى مروّث. لهسهرهتاوه، شاعير (شويّ)ى

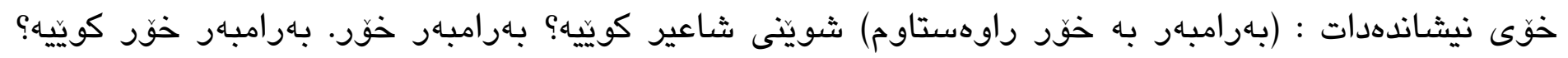
ئيزهيه، ئيزهش (بوون)ه، جهختكردنهوهيه لهسهر جيهان/بوون/كاردوون. باسكردنه لهوهى كه "بوون" ئهوكاته

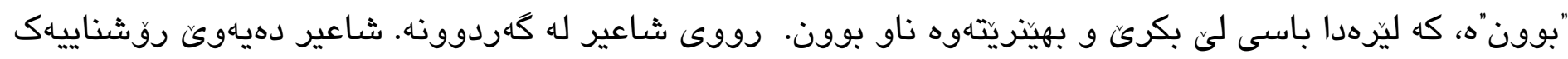

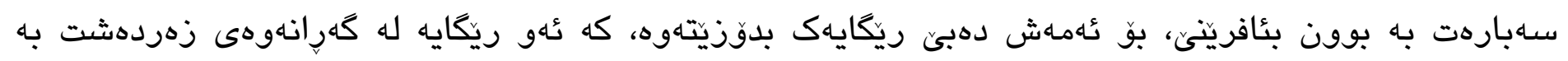

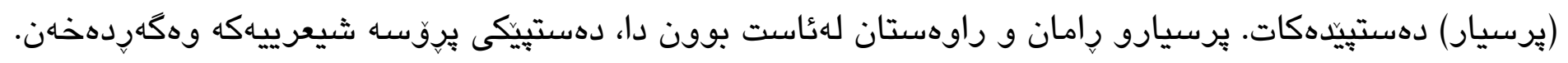

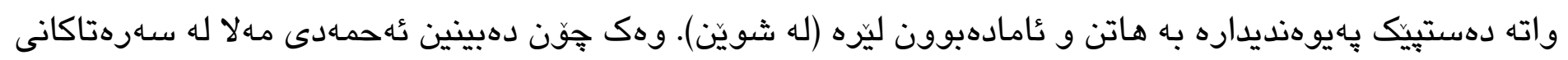

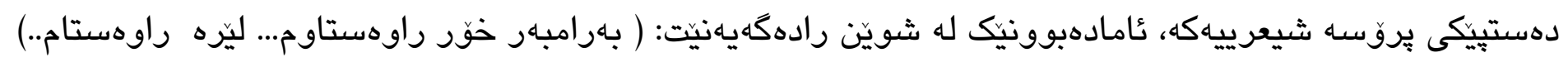

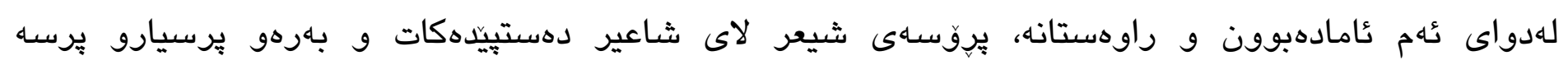
وجودييهكان دريزّدهبيتهوه.

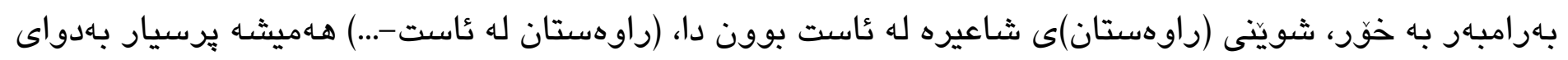

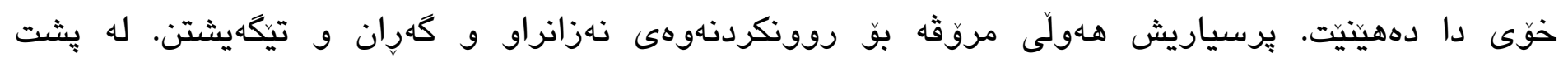

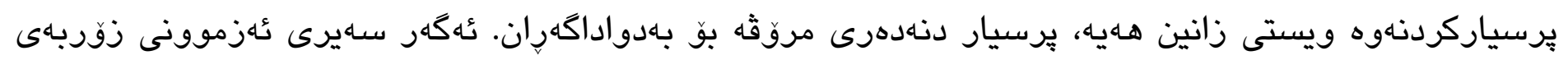

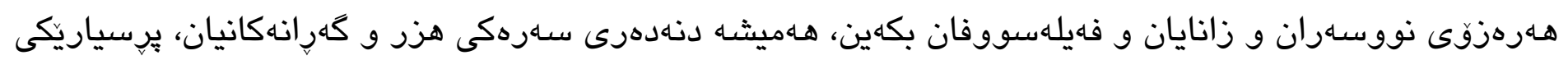

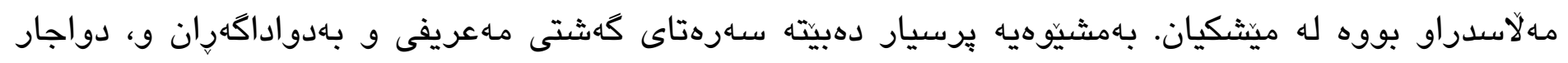

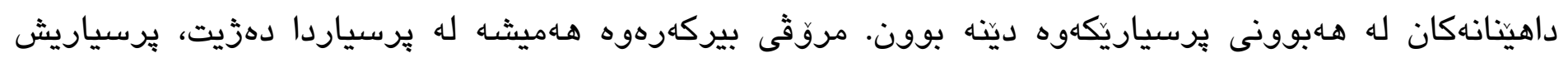

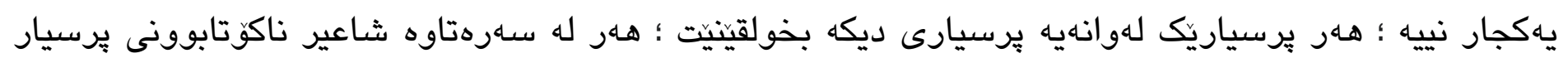


ثامورا تف خاوهن شهش كزنكى، شهش لدهروازهى، شهش برسيارى، مهر يرسياريكيشت لدهيان برسيارن، كزنكى

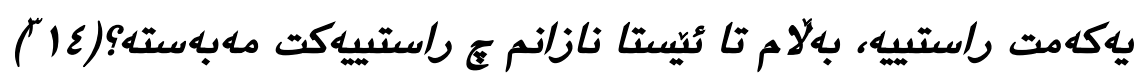

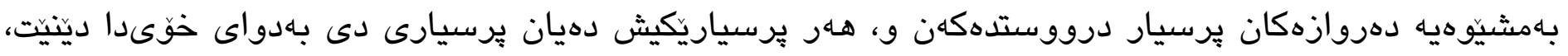

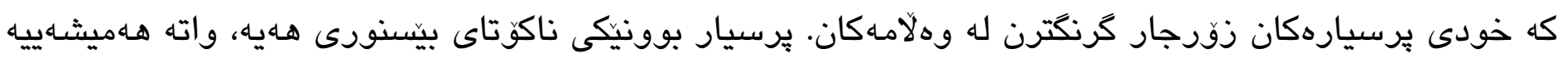

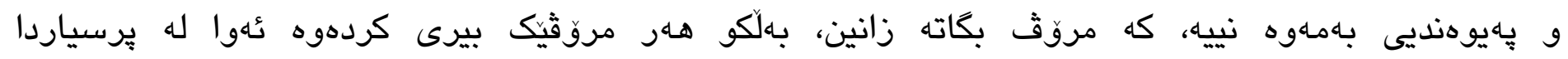

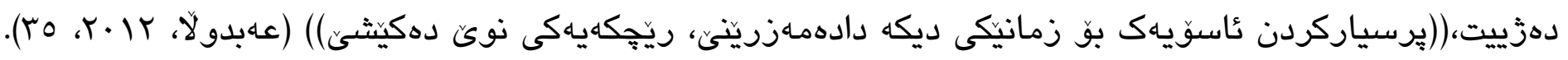

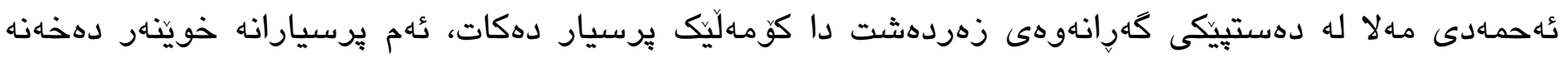

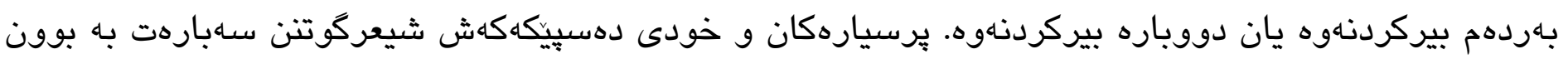

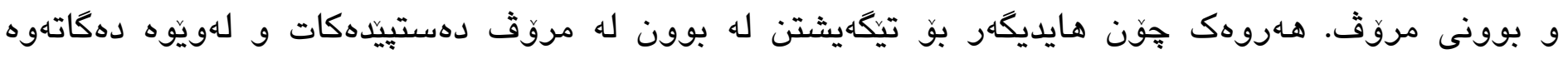

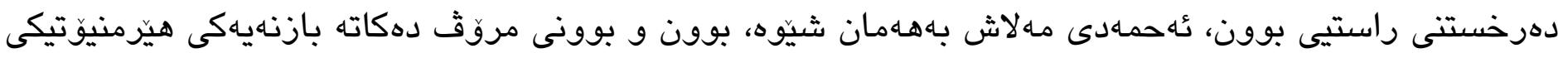

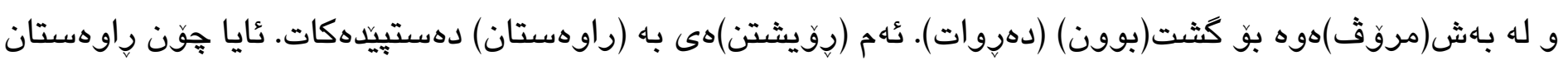

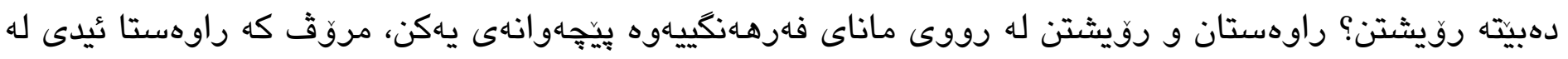

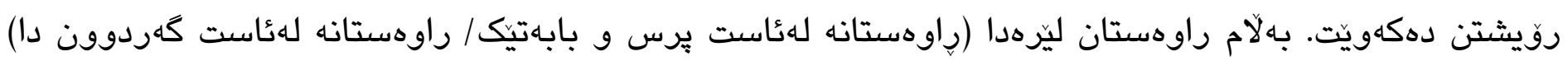

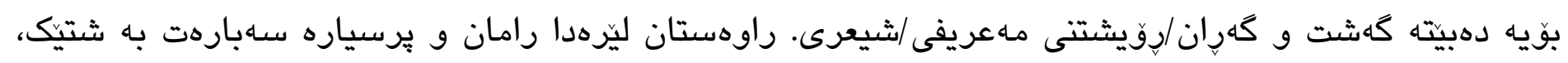

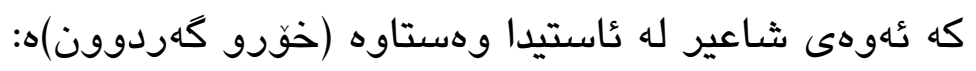
له بهرامبهر خُور راوهستاوم

\section{هيثشتا نازانم ئهو بق من مهللهاتووه يا من بو ئهو؟}

ثُهم راوهستانه جههندين بِرسيارى بهدوادا ديتّ ؛ شاعير له رووى فيزيكييهوه وهستاوه، بهلاّم شيعر، كه دهكاته خهيال

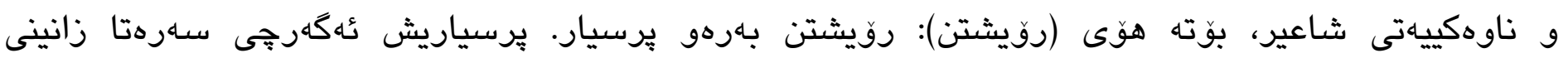

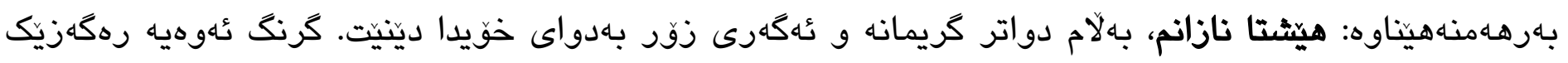

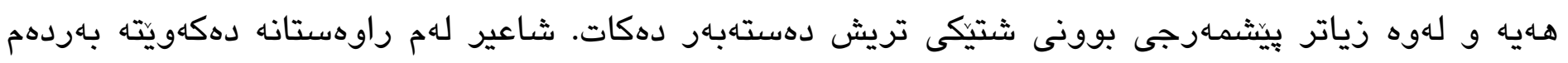

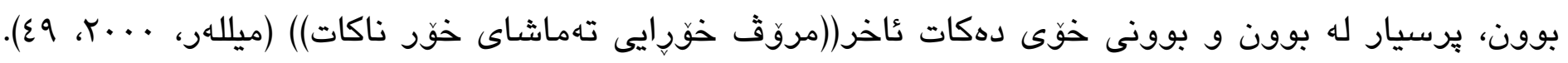

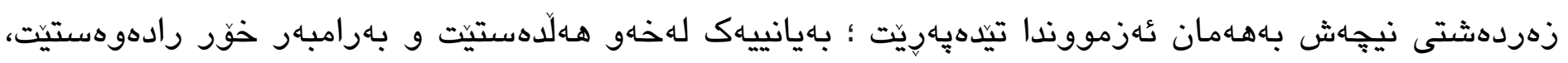

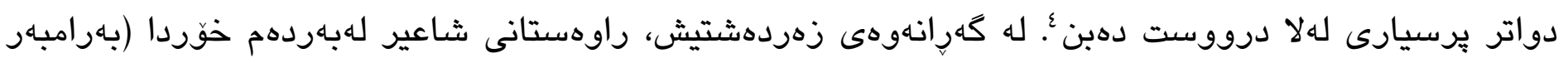

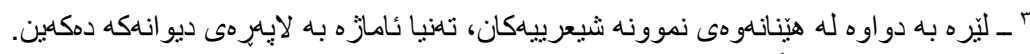

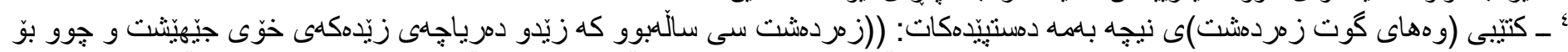

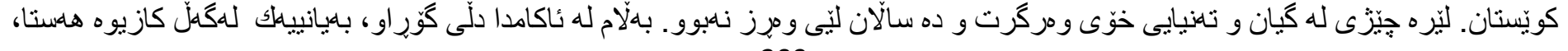
209

DOI:https://doi.org/10.26750/Vol(8).No(3).Paper11 http://journal.uor.edu.krd/index.php/JUR Vol.8. No.3,September.2021 


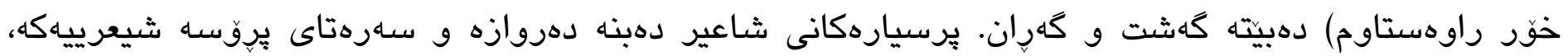

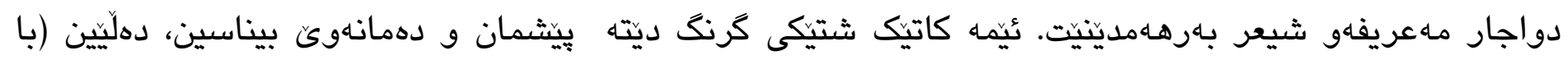

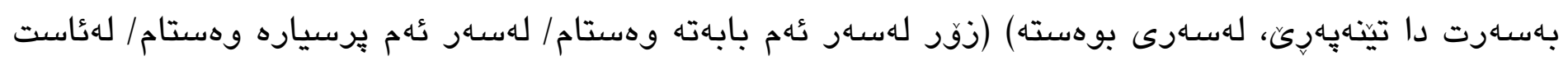

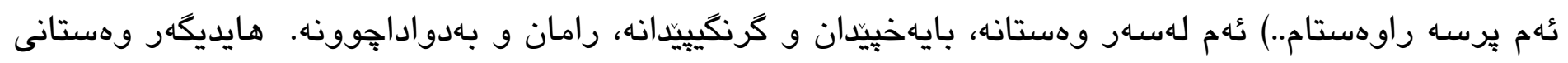

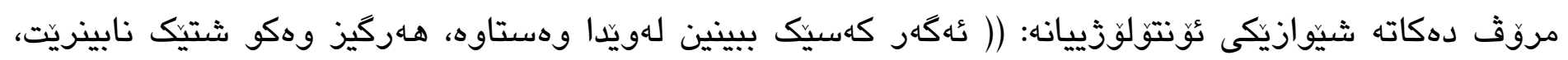

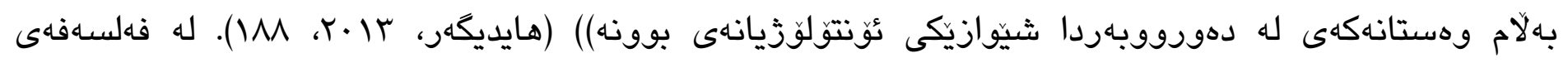

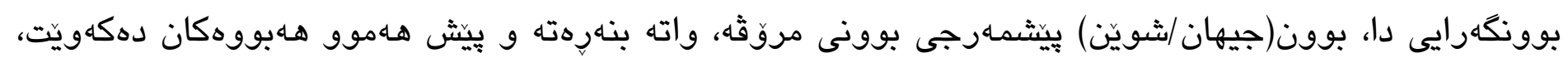
خودى زاراوهى (دازاين)يش، كه هايديكَر بوّ بوونى مروقى بهكاردههينيت، ئهم ئامازّه و واتايهى تيدايه و بهماناى(بوون ليّره) ديّت. (ليّره ) كه دهكاته جيهان، يِيَش بوونى مروق دهكهويّت ((بّ دازاين بوون لهنيو جيهان

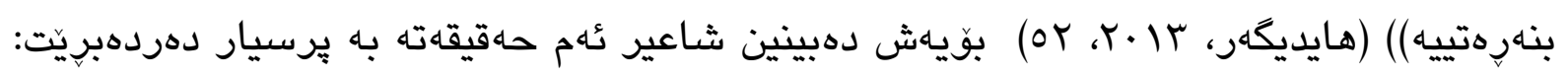

\section{تايا زمان له لدرهوهى بوقن هيج واتايهكى دهبي؟ 10}

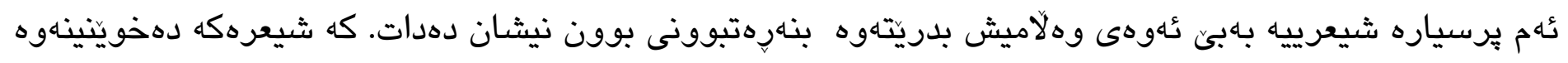

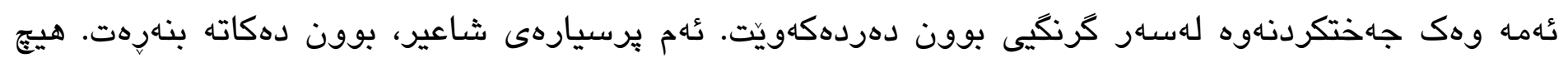

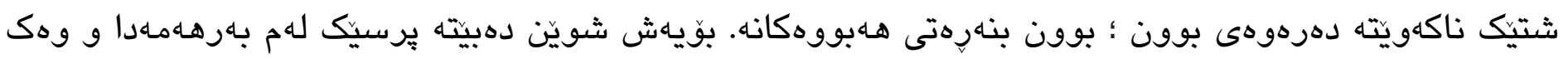

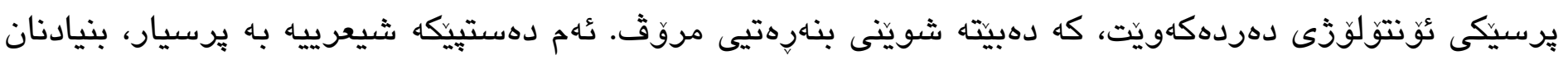

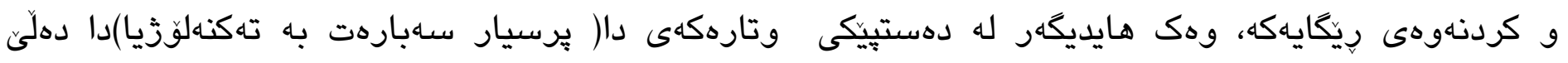

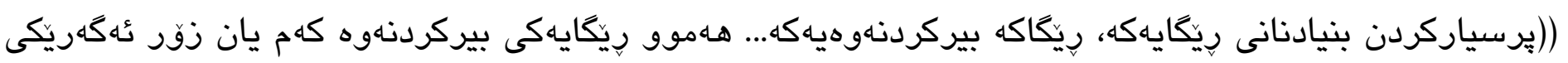

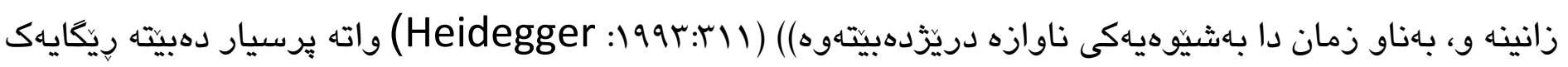

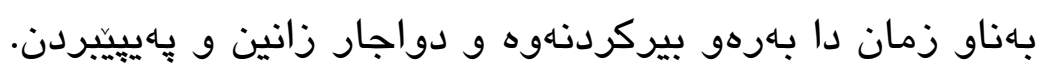

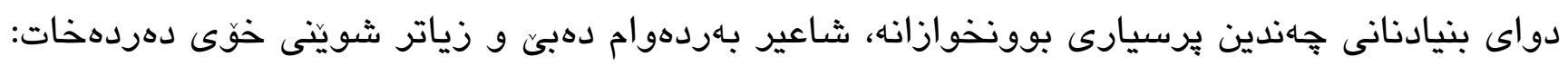
ليّره رِوهستاوم: تُهم كهردوقنه لهناومدا كهثه لدكات، لهناو مندا زينلوقه لدماكونَ تُهم راستييه بخومهوه (10)

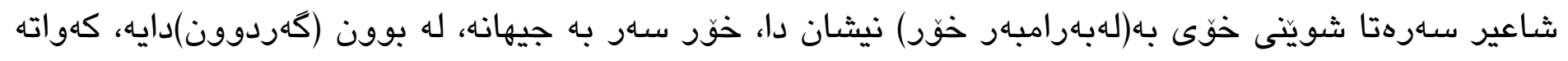

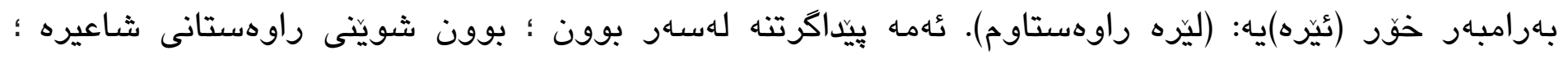

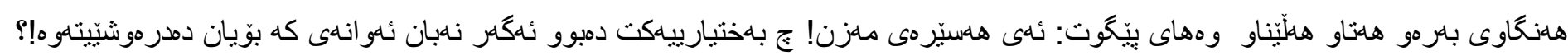
210

(ن: (ن DOI:https://doi.org/10.26750/Vol(8).No(3).Paper11 http://journal.uor.edu.krd/index.php/JUR Vol.8. No.3,September.2021 


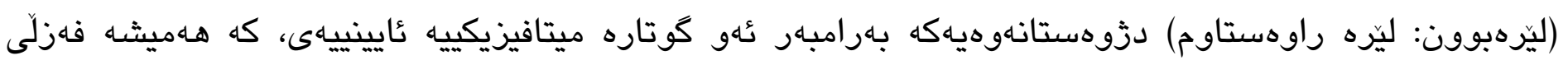

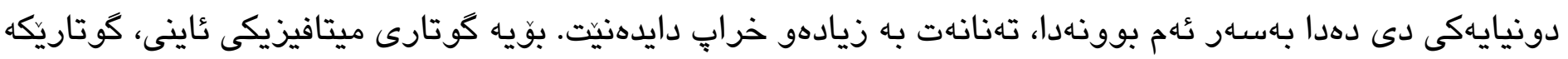

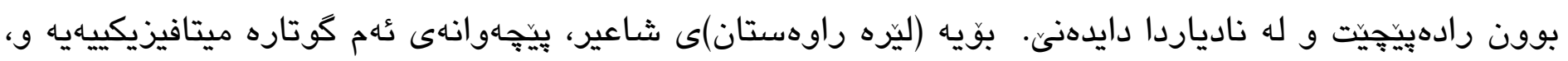

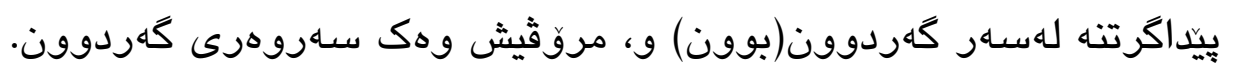

جهامكى (ليّره) كه شاعير دهلّيت (ليّره راوهتاوم...) ئامازهيه بو شويّن و، هايديكهر له بوون و كات دا، زياد له

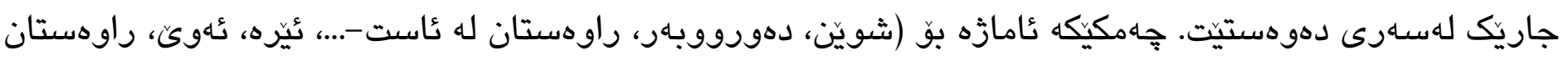

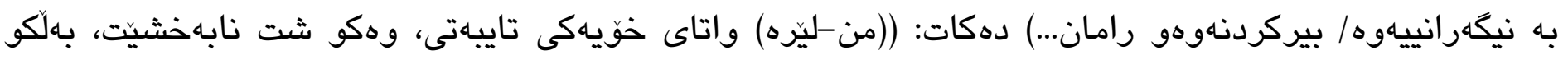

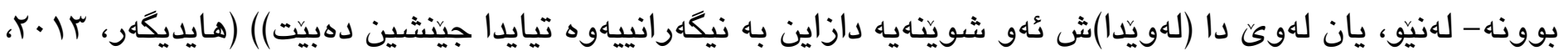

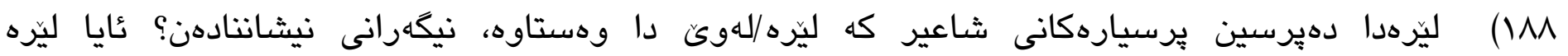

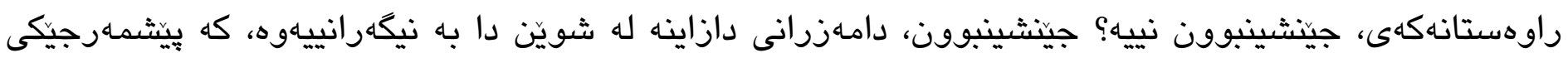

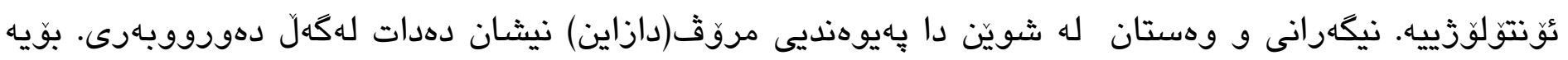

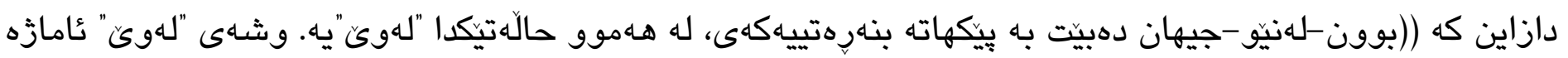

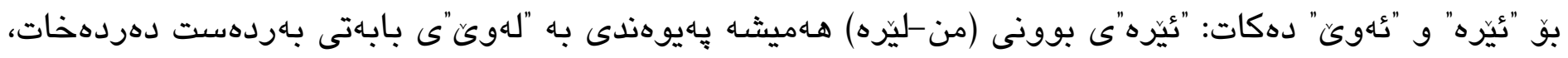

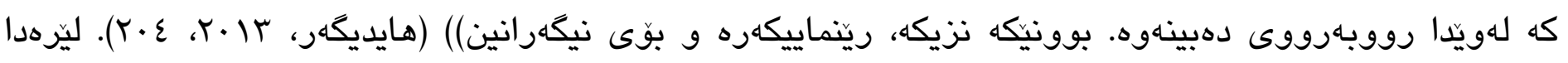

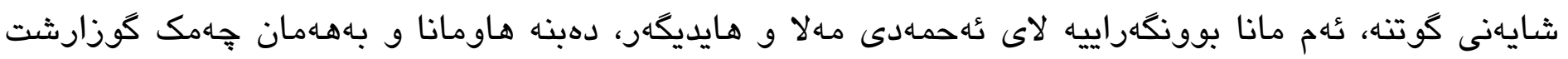

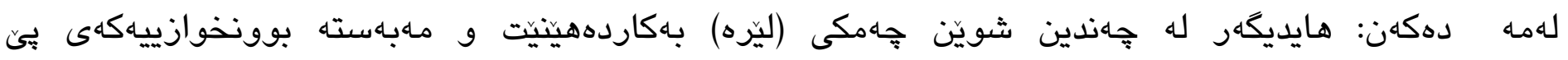

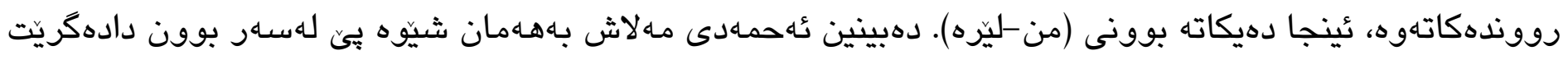

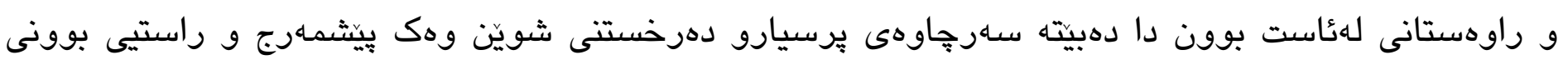
مروّث:

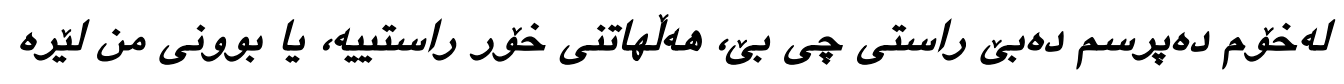
يان بوونى هـردووكمان؟ له راستيدا ئهم بِرسيارانه، وهك خستمانتهِوو، بِرسيارى ئونتولوَذين.

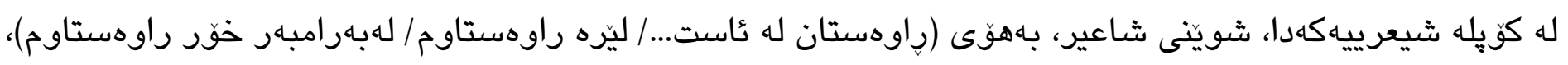

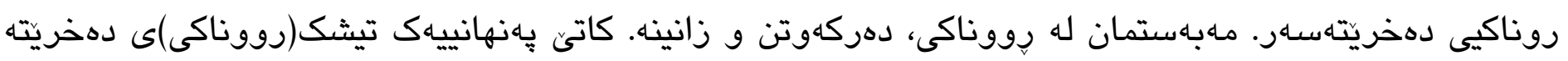

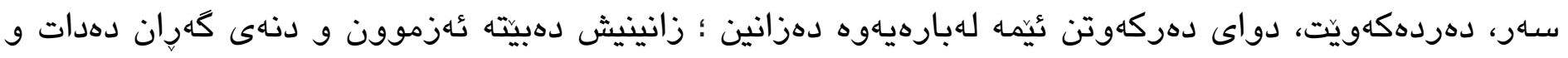

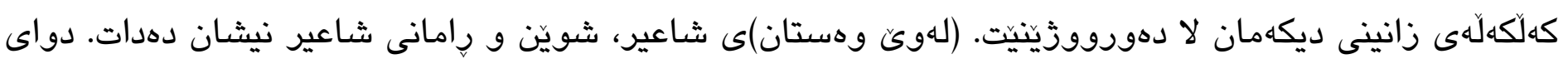


ئهمه شاعير دهست به كُهان و بِرسيارهكانى دهكات، رووناكى دهخاته سهار بوونى و نيشانى ئيماهى خوينّاهريش

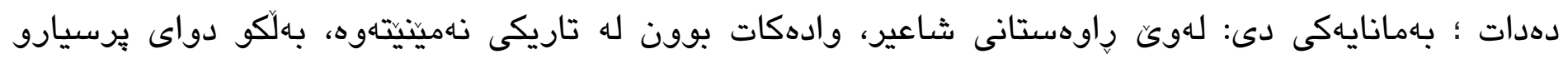

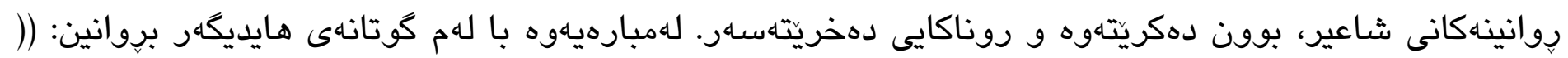

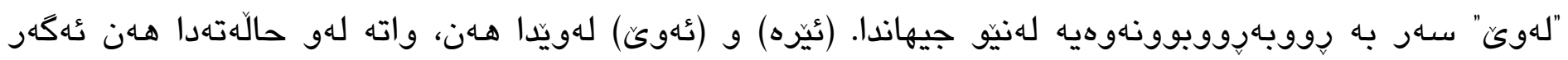

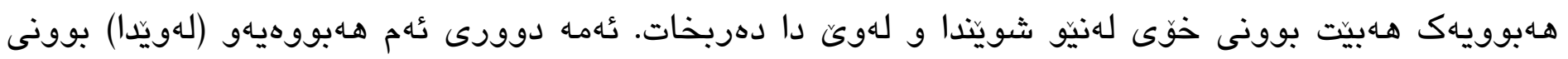

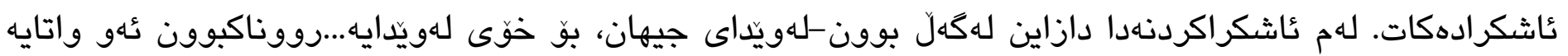

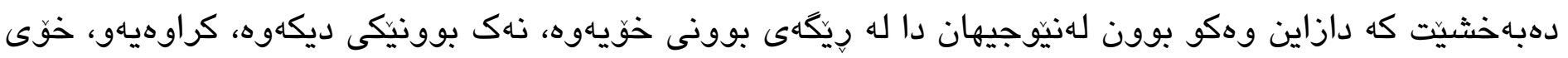

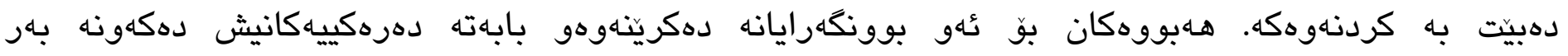

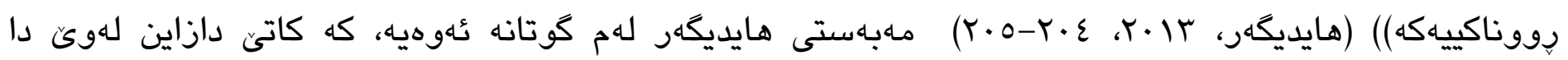

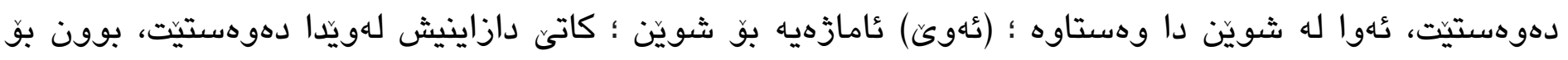

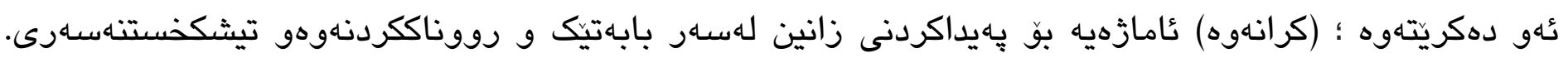

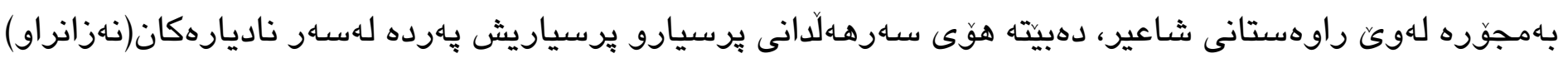

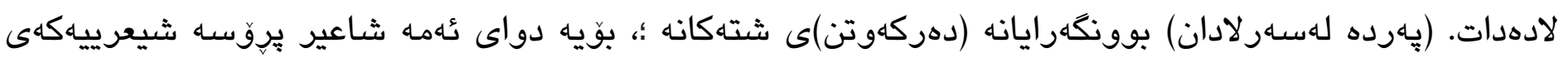
بارجهاته دهكات.

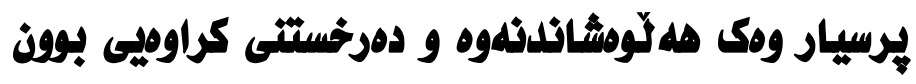

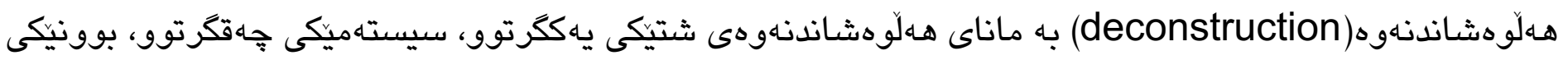

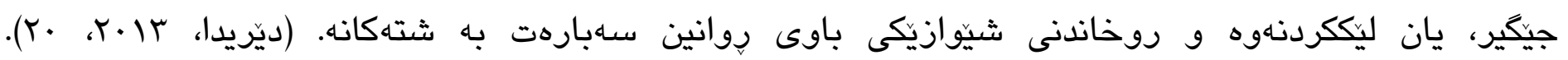

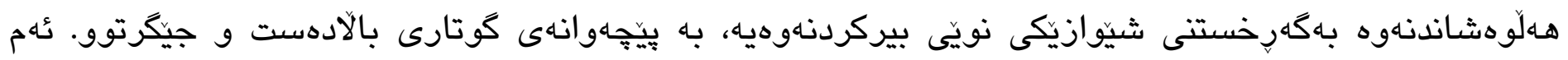

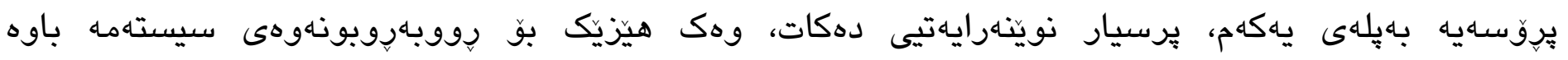

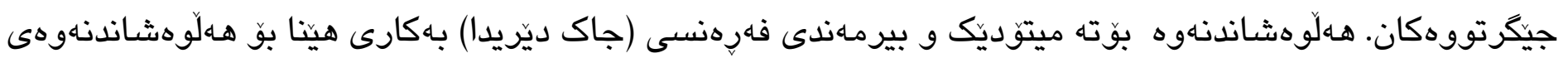

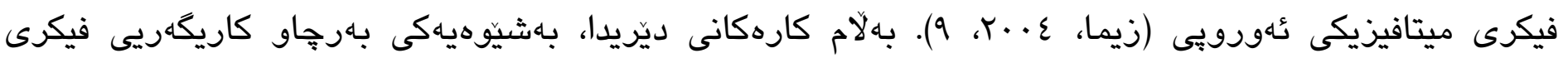

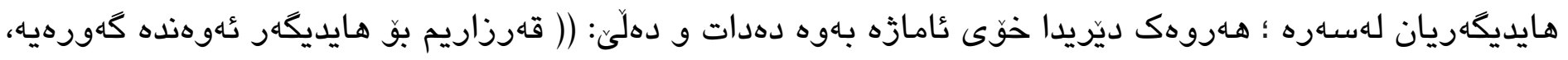

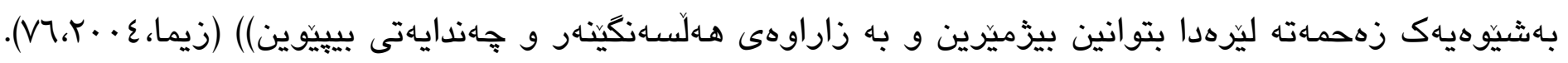

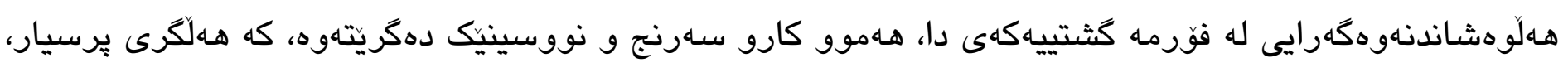

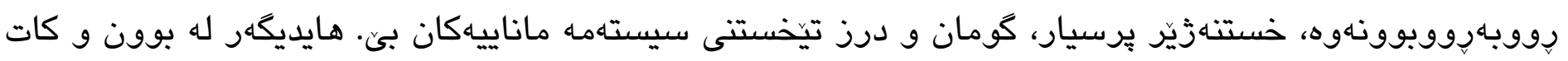

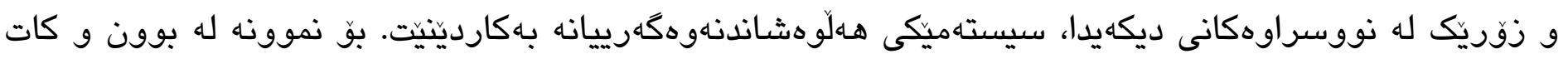

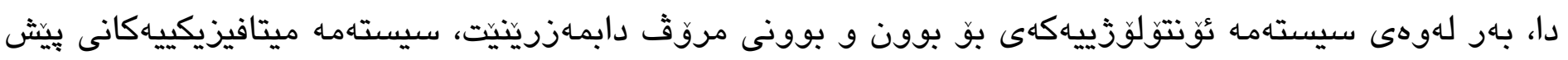




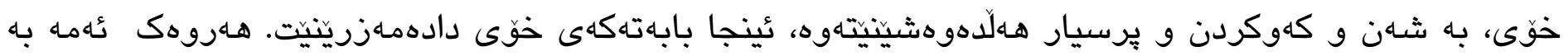

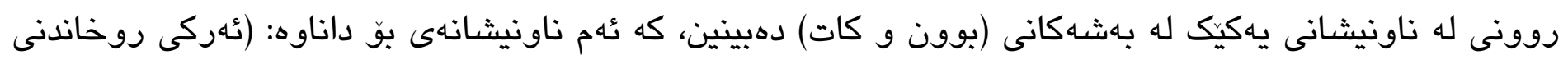

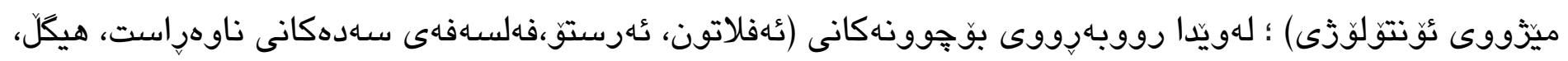

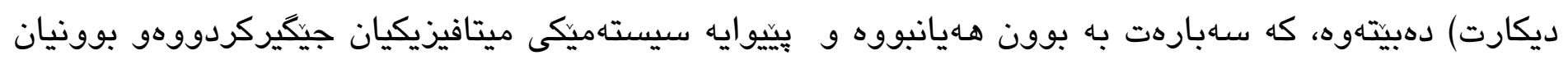

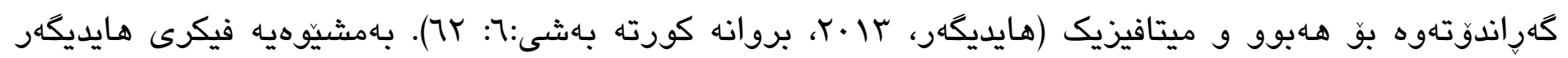

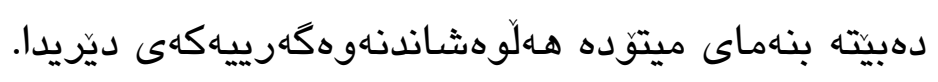

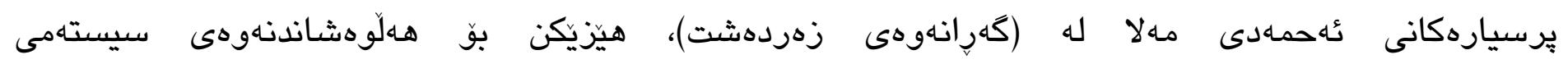

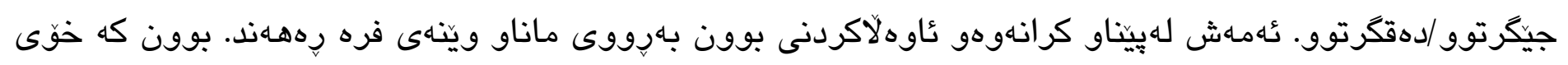

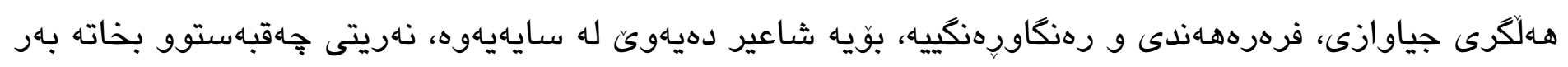

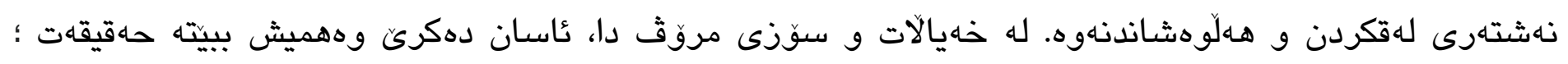

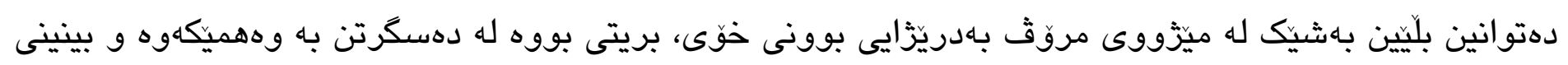

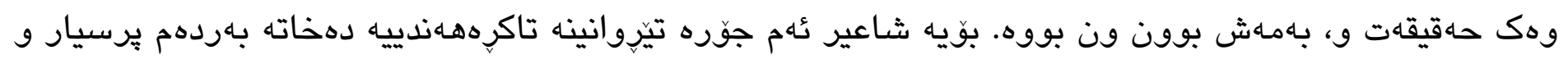

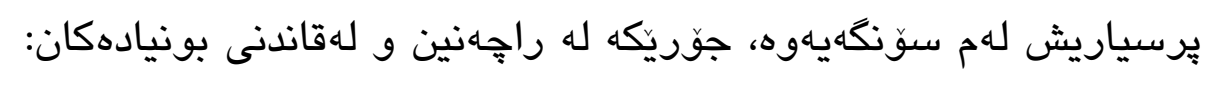

ئاهورا، من بشت لهوانه دهكه كه كويلهى راستين لدهيهرستن بو ئهوهى ئاسمانهان به وهمم رهنكاورذنك بكهن تاكو نيوهى شهو لهكهل ئهوانه دهويّم كه تهنها مهر يهك راستى لدهبين ناز/نم ئهوانهى يهك راستى دهبينن، ئهوهى دهبينن راستييه يا نهزانييه؟! (ع!).

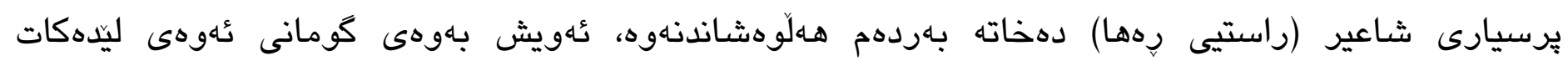

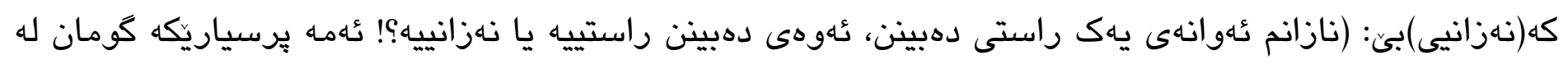

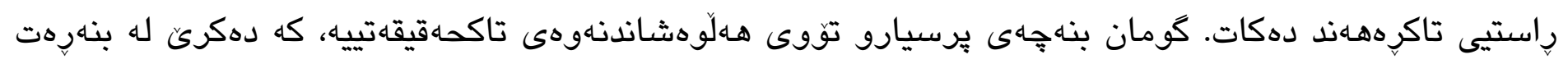

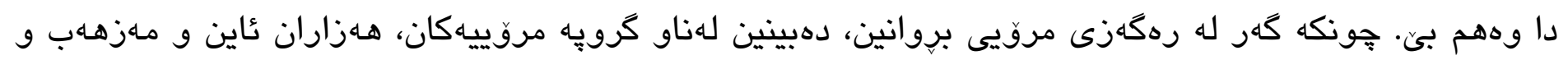

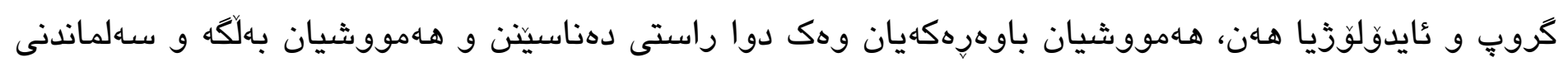

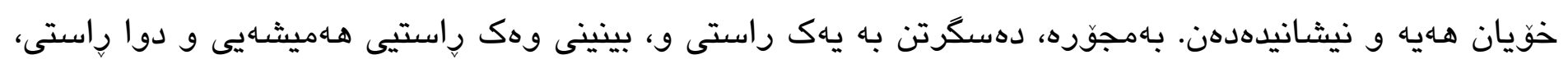

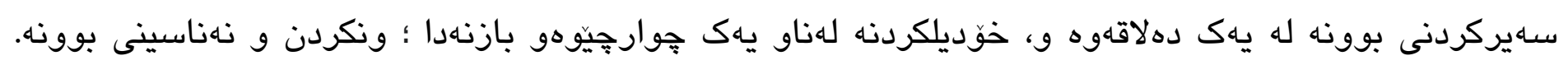

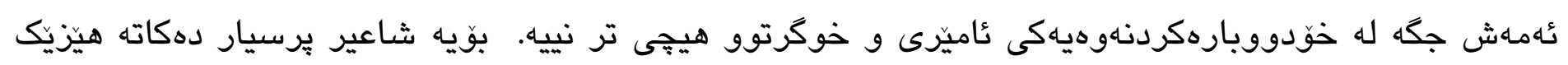

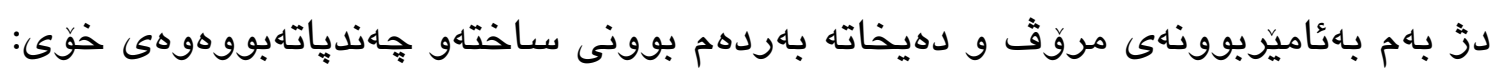
213

DOI:https://doi.org/10.26750/Vol(8).No(3).Paper11 http://journal.uor.edu.krd/index.php/JUR Vol.8. No.3,September.2021 
غويارى راماتن مهموومانى كردبووه يهيكهركهليكي له نمهك وهكو ئاميّره تئقتوماتيكييكان مهلدهستاين و دادهنيشتينهوه دادهنيشتين و مهلدهستاينهوه تُينسانى ئاميّر بِّ كوكى لدهِّى؟؟ ...

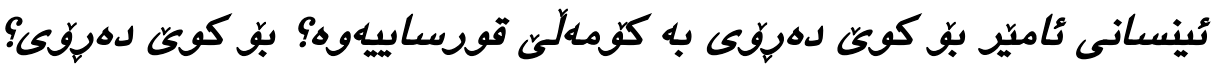
جاوهكانت مهموف رِّرّكى مهمان ديمهن لدبينيّ هـمان باغجهى غويارلينيشتوو مهمان ريّكاى خُولاوى مهمان تهلاريى مردوو. (9 (1) بهمشيّوهيه خوّديلكردن لهناو بازنهدا، جاوهكانى مروّق دادهخات لهئاست بينينى دونياى دهرهوهى بازنهكه. ثُهماش

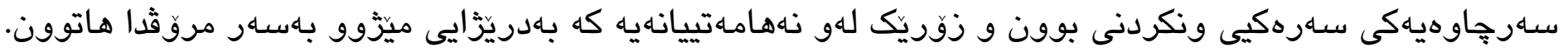

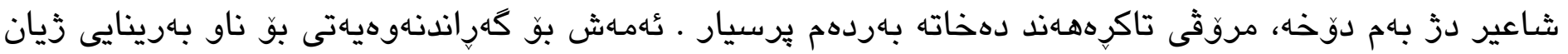

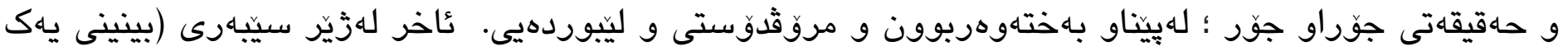
راستى) دا مروق هيندهى نالآندوويانى، هينّده دلّثاد و بهختهوهر نهبووه، هينّدى بوونى تاريك كردووه، رووناكى

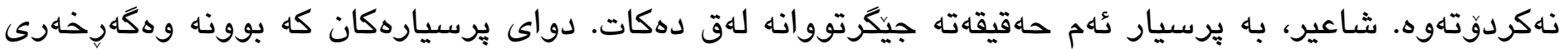
بيركردناوه و رِاوهستان له ئاست بوون دا، شيعر لاى شاعير دهبيته دامهزراندنى كوتاريكى خاكدوست و ئيّرهدوست، نهك ئهويِيه رست:

ئهبهدييهتى نويم دابهست قيلهانم تيكشكاندو "تُيره" م بوزٔانلهوه (VN)

ئهجهادييهتى نوىّ، دامهزراندنى كوتاريكى ديكهيه، كه دواى برسيارو رامانهانى شاعير بهرهـمهاتووه، جونكه

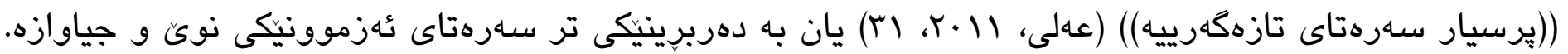

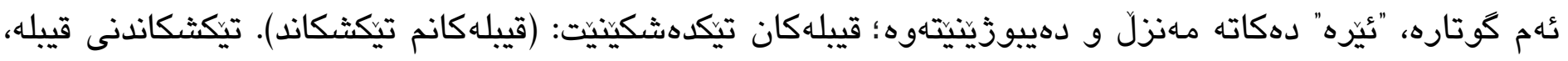




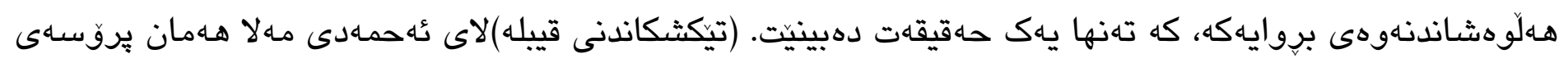

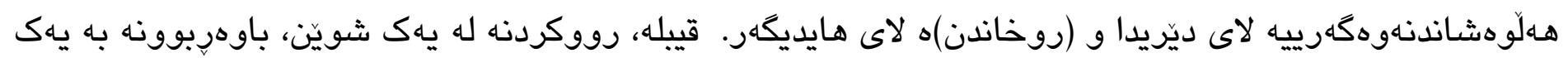

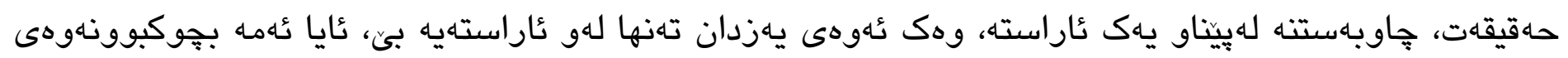

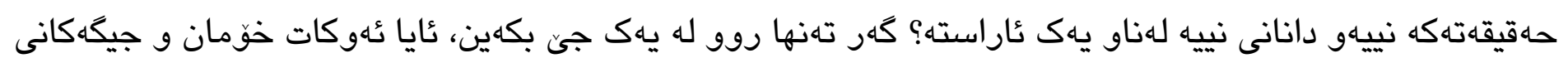
دى ون ناكهين؟ بينينى يهك جي، نهبينيى جييهكانى تره، دهستكرتن بهتاكه يـك حهقيقهت، لهبيركردنى حهقيقهتهانى

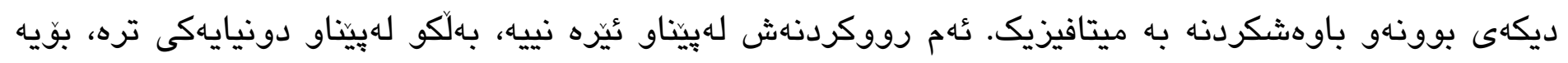

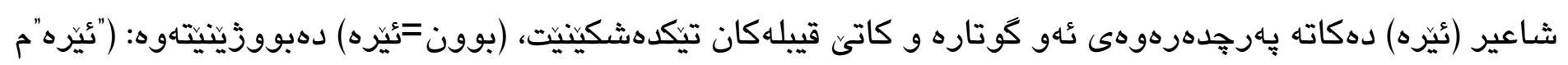
بوزاندهوه). دواجار بوونيش فراوان دهات.

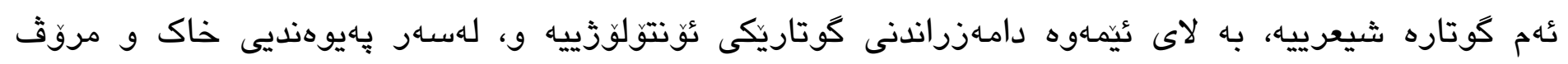

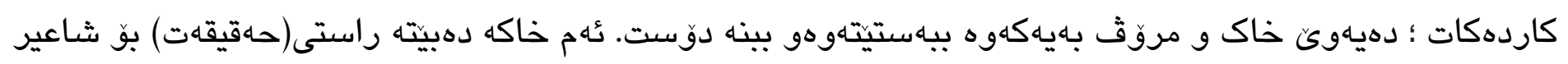

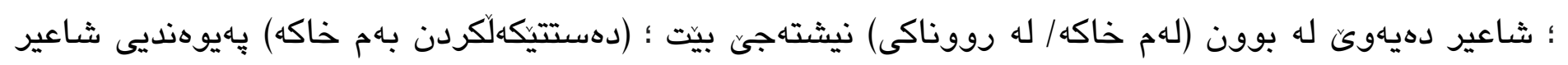

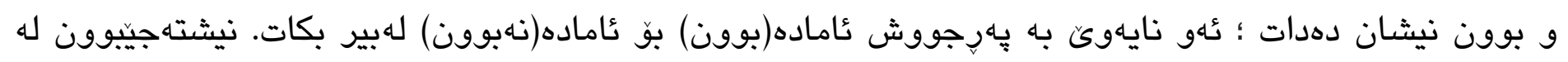
رووناكى، نيشتهينيوونه له زانين، زانين و رووناكى دهستهخوشكن، نازانين و تاريكيش هـروا. رووناكى ثامازذهيه بو حهقيقهتى بوون، هـروهك جَّن دهبينين له ديّرهكانى دواتر دا شاعير رووناكييهكه شـهبهنكدارتر دهكات و دهيبهستيتهوه بـه بوون و راستى:

من لدماهوى له لهناو ريوفناكى نيشتهجيَ بم

تُهو رووناكييي

لهنيو عاو و ههتاو و كل و با دايه

ئهو رووناكييهى

راستييه (Yo).

ليّرهدا شـاعير (رووناكى) و (راستى)ى بهيه كهوه بهستوونهتهوه ؛ رووناكى هـهر دهكاته راستى، راستيش به بوّجوونى

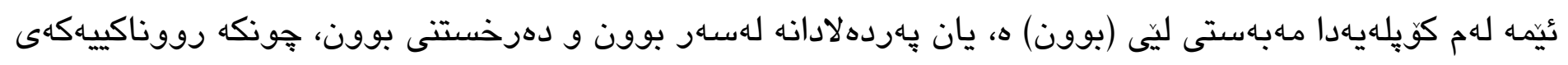

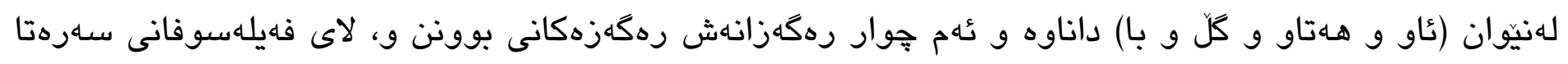

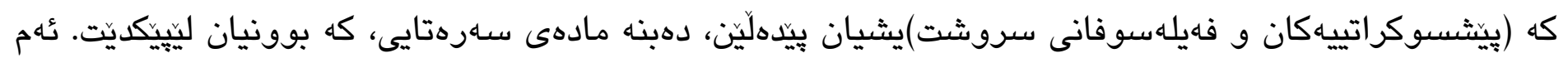

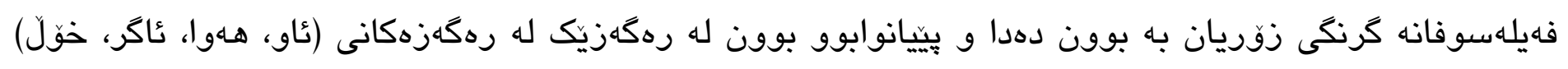




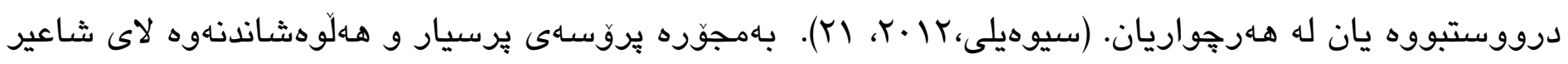

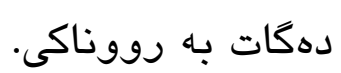

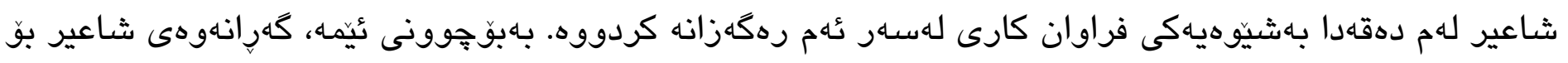

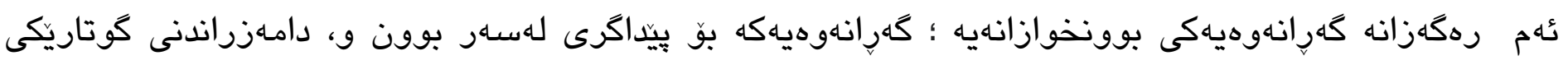

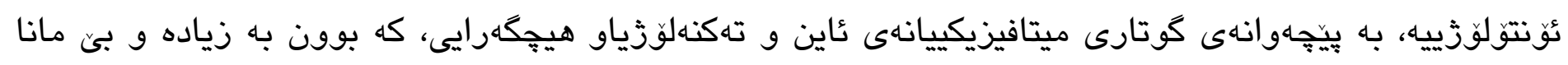

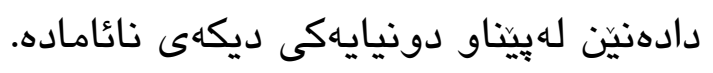

\section{تُنجمام}

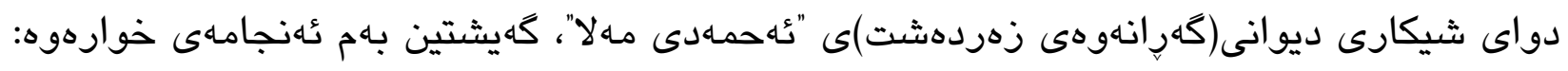

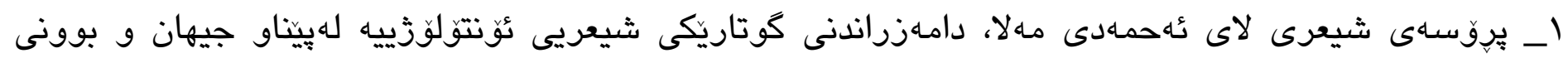
مروّڤ.

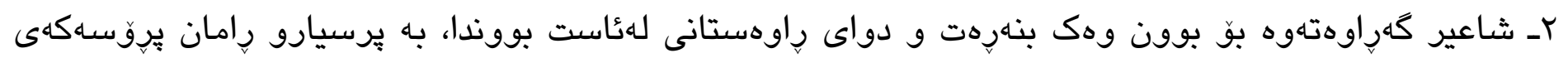

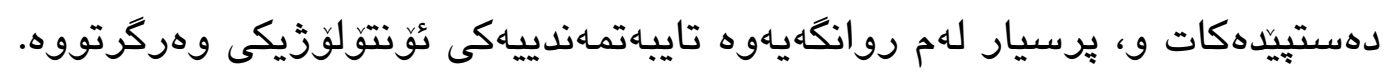

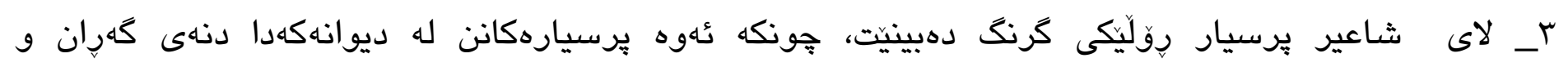

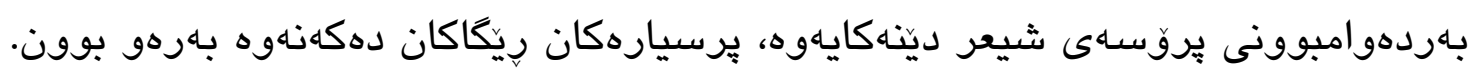

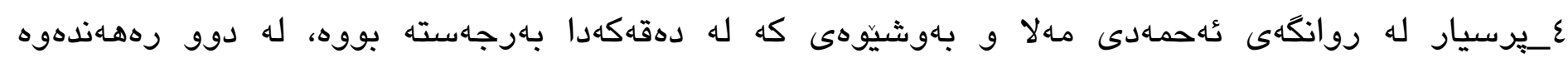

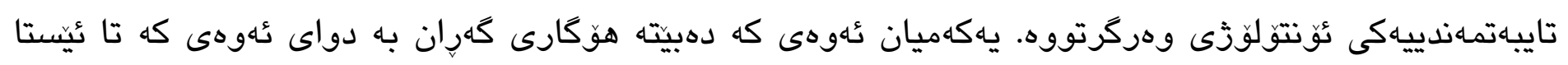

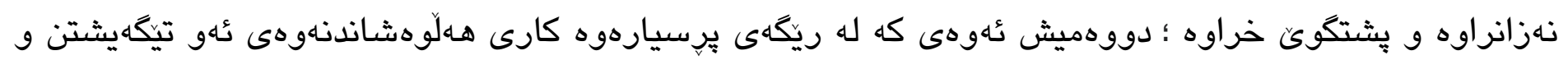

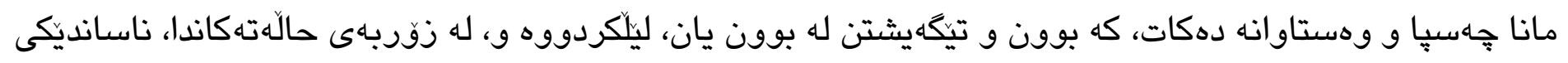

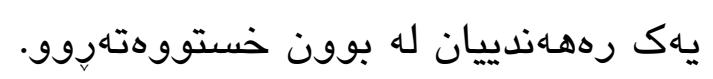




\title{
Question as an Ontological Principle in Ahmadi Mala's" Return of Zardasht
}

\section{Hazhar Ahmed Abdulghafur}

Kurdish Department, Faculty of Arts, Soran University, Soran, Kurdistan Region, Iraq.

E-mail: Hazhar.abdulghafur@ soran.edu.iq

\section{Mohamed Nabee Ibrahim}

Shahid Abdulrahman Highschool, Directorate of Soran Education, Soran, Kurdistan Region, Iraq.

E-mail: Mhamad.nabe88@gmail.com

\begin{abstract}
:
Existence as the basis of all that exists (in general) is an important element of philosophy and poetry. Throughout histroy, less or more, attantion has been paid to existence mater in all its dimentions by philosophers and poets and thinkers. In Kurdish literature, the reflection and reaction of this subject is clearly noticeable in the poetry products. Thus, this research, entitled "Question as an ontology principle in Ahmadi Mala's" Return of Zardasht" is focused on, the closeness of poetry and philosophy and the probablity of expressing the philosophy in two pieces of poetry and literature; works on the existence, and tries to analys and interpret the context of poetry of (Return of Zardasht) of 'Ahmadi Mala'. This is to bring antological questions foth as preconditional characteristic. The question whereby as motivation of searching for the existence, and then rising it, introduces human as delicated creature and provides the path to reach exsitence and its very facts.
\end{abstract}

Keywords: Existence, Question, Ontology, Heidegger. 


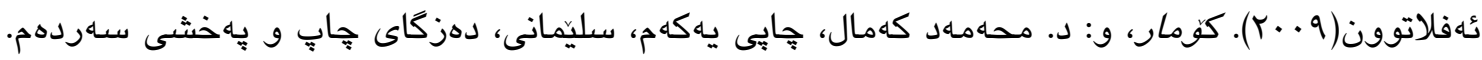

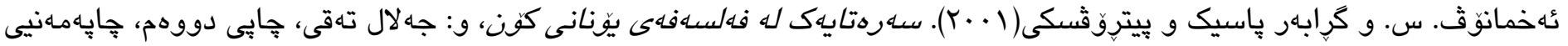
زاموا.

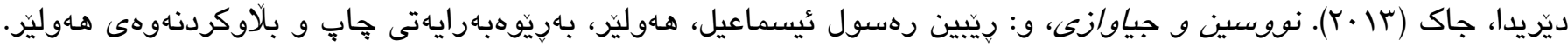

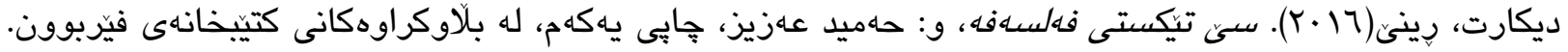

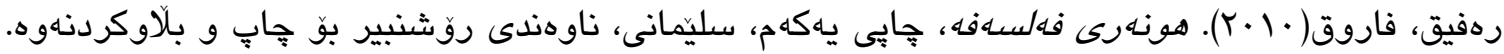

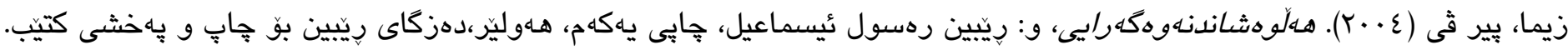

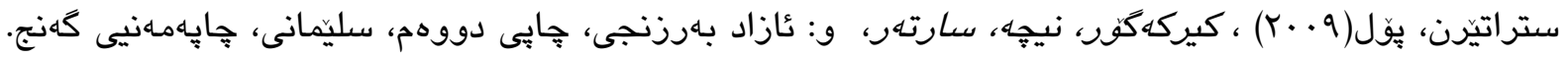

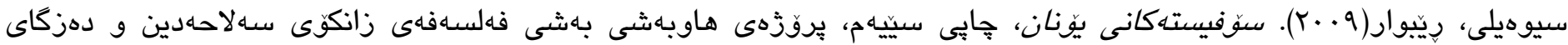
موكريانى، هـاوليَر، جِايخانهى هاوسـر.

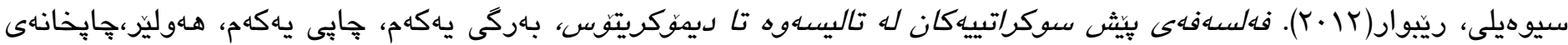
روَّهـلات.

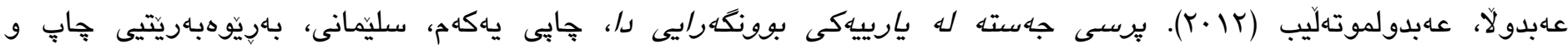
بلأوكردناهوهى سليّمانى.

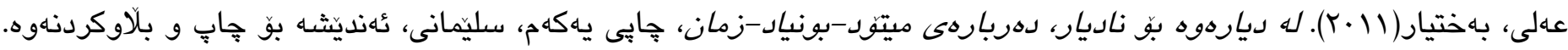

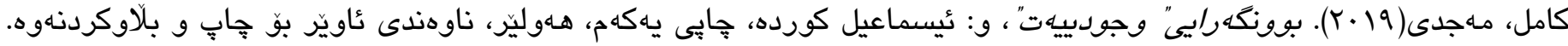

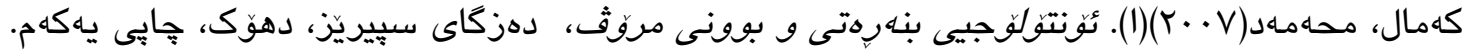

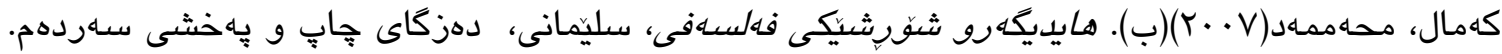

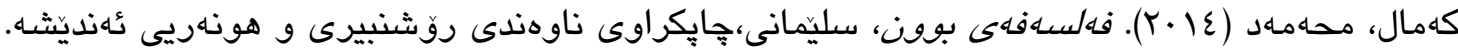


Journal of University of Raparin $\quad$ كوّقارى زانكوّى رابِّرين $\quad$ E-ISSN: 2522 - 7130 P-ISSN: 2410 - 1036

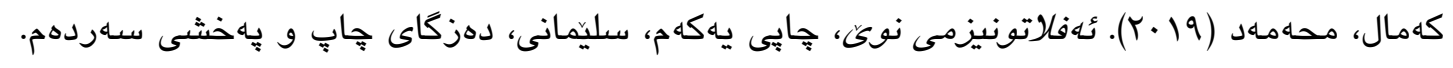

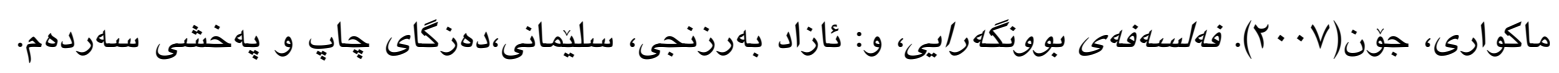

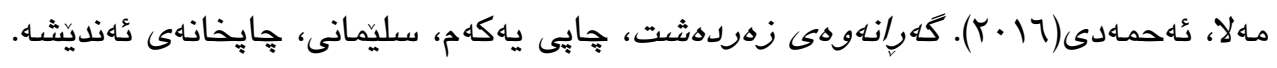

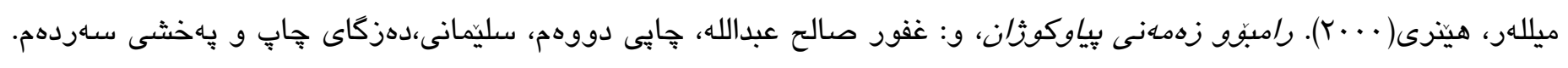

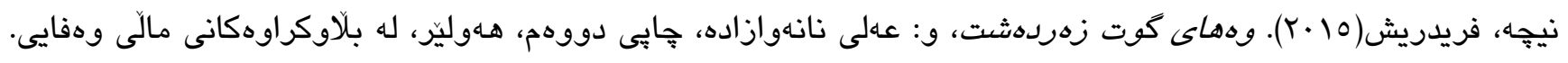

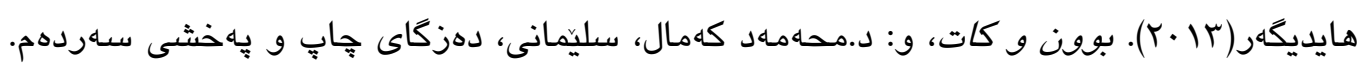

martin Heidegger، the question concerning Technology، in basic writings، trsanslated by David Farrell Krell، HarperCollins publishers‘ new York‘ 1993. 